Article

\title{
Formation of Hydrogen Sulfide in Wine: Interactions between Copper and Sulfur Dioxide
}

\author{
Marlize Z. Bekker *, Mark E. Smith, Paul A. Smith and Eric N. Wilkes \\ The Australian Wine Research Institute, P.O. Box 197, Glen Osmond, 5064 South Australia, Australia; \\ mark.smith@awri.com.au (M.E.S.); paul.smith@awri.com.au (P.A.S.); eric.wilkes@awri.com.au (E.N.W.) \\ * Correspondence: marlize.bekker@awri.com.au; Tel.: +61-8-8313-0357 \\ Academic Editors: Susan E. Ebeler and Helene Hopfer \\ Received: 30 June 2016; Accepted: 6 September 2016; Published: 10 September 2016
}

\begin{abstract}
The combined synergistic effects of copper $\left(\mathrm{Cu}^{2+}\right)$ and sulfur dioxide $\left(\mathrm{SO}_{2}\right)$ on the formation of hydrogen sulfide $\left(\mathrm{H}_{2} \mathrm{~S}\right)$ in Verdelho and Shiraz wine samples post-bottling was studied over a 12-month period. The combined treatment of $\mathrm{Cu}^{2+}$ and $\mathrm{SO}_{2}$ significantly increased $\mathrm{H}_{2} \mathrm{~S}$ formation in Verdelho wines samples that were not previously treated with either $\mathrm{Cu}^{2+}$ or $\mathrm{SO}_{2}$. The formation of $\mathrm{H}_{2} \mathrm{~S}$ produced through $\mathrm{Cu}^{2+}$ mediated reactions was likely either: (a) directly through the interaction of $\mathrm{SO}_{2}$ with either $\mathrm{Cu}^{2+}$ or $\mathrm{H}_{2} \mathrm{~S}$; or (b) indirectly through the interaction of $\mathrm{SO}_{2}$ with other wine matrix compounds. To gain better understanding of the mechanisms responsible for the significant increases in $\mathrm{H}_{2} \mathrm{~S}$ concentration in the Verdelho samples, the interaction between $\mathrm{Cu}^{2+}$ and $\mathrm{SO}_{2}$ was studied in a model wine matrix with and without the presence of a representative thiol quenching compound (4-methylbenzoquinone, $4 \mathrm{MBQ}$ ). In these model studies, the importance of naturally occurring wine compounds and wine additives, such as quinones, $\mathrm{SO}_{2}$, and metal ions, in modulating the formation of $\mathrm{H}_{2} \mathrm{~S}$ post-bottling was demonstrated. When present in equimolar concentrations a 1:1 ratio of $\mathrm{H}_{2} \mathrm{~S}$ - and $\mathrm{SO}_{2}$-catechol adducts were produced. At wine relevant concentrations, however, only $\mathrm{SO}_{2}$-adducts were produced, reinforcing that the competition reactions of sulfur nucleophiles, such as $\mathrm{H}_{2} \mathrm{~S}$ and $\mathrm{SO}_{2}$, with wine matrix compounds play a critical role in modulating final $\mathrm{H}_{2} \mathrm{~S}$ concentrations in wines.
\end{abstract}

Keywords: reductive aromas; hydrogen sulfide; quinone; wine; copper; sulfur dioxide

\section{Introduction}

The origin and management of volatile sulfur compounds (VSCs) in wine is a topic that concerns many winemakers, as these compounds have a significant impact on wine aroma as well as wine quality [1]. Volatile sulfur compounds such as hydrogen sulfide $\left(\mathrm{H}_{2} \mathrm{~S}\right)$ contribute negatively to wine quality and are considered a wine fault when present at concentrations greater than its odor threshold (OT) value of 1.1-1.6 $\mu \mathrm{g} / \mathrm{L}$ [2]. As one of the main compounds contributing to "reduced" characters in wine, $\mathrm{H}_{2} \mathrm{~S}$ imparts aromas of rotten egg and sewage when present in high concentrations, however, when present in low concentrations $\mathrm{H}_{2} \mathrm{~S}$ can add complexity to wine aroma [2]. While the release and subsequent perception of $\mathrm{H}_{2} \mathrm{~S}$ into the wine headspace is affected by the wine matrix, the contribution of individual wine matrix components on VSC perception, such as $\mathrm{H}_{2} \mathrm{~S}$, has not yet been determined [3].

The reaction pathways for $\mathrm{H}_{2} \mathrm{~S}$ formation post-bottling are not yet as well defined as those during fermentation, however, certain key factors affecting $\mathrm{H}_{2} \mathrm{~S}$ concentration post-bottling have recently been elucidated. It is known that decreased oxygen concentrations during fermentation as well as during wine storage conditions are associated with increased $\mathrm{H}_{2} \mathrm{~S}$ concentrations in wines post-bottling [4-6]. Franco-Luesma and Ferreira [7] have recently shown that $\mathrm{H}_{2} \mathrm{~S}$ is present in both free and bound forms in wine and the percentage of free and bound forms are related to the trace metal content of the wine. According to Franco-Luesma and Ferreira, both de novo formation of $\mathrm{H}_{2} \mathrm{~S}$ from precursor 
compounds as well as the release of $\mathrm{H}_{2} \mathrm{~S}$ from metal complexes contribute to the final concentration of $\mathrm{H}_{2} \mathrm{~S}$ formation in wines post-bottling, with release from metal complexes responsible for the majority of $\mathrm{H}_{2} \mathrm{~S}$ produced in red wines, and de novo formation responsible for the majority of $\mathrm{H}_{2} \mathrm{~S}$ produced in white wines and rosé wines [7]. Additionally, Franco-Luesma suggests that the release of free $\mathrm{H}_{2} \mathrm{~S}$ and $\mathrm{MeSH}$ from bound sources are a function of a decrease in redox potential of wine [8].

A number of studies have also highlighted the important catalytic role of metals such as $\mathrm{Cu}^{2+}$, $\mathrm{Fe}^{3+}, \mathrm{Mn}^{2+}, \mathrm{Al}^{3+}$, and $\mathrm{Zn}^{2+}$ ions in VSC formation in wine [4,9-11]. Metal ions naturally occur in wines at trace concentrations and their final concentrations in finished wine are influenced by the use of metal containing pesticides and herbicides, processing aids, and winemaking equipment. However, the addition of $\mathrm{Cu}^{2+}$ (copper can exist in both $\mathrm{Cu}^{+}$and $\mathrm{Cu}^{2+}$ oxidation states in wine; thus, in this manuscript, " $\mathrm{Cu}^{2+"}$ is used when the authors refer to the oxidation state in which copper was added to the wine) to wines through the use of copper sulfate as a fining agent applied to decrease reductive aromas in wine, remains the main use of metals that results in increased residual concentration of the metal post-bottling [5]. While the mechanism of copper fining is not yet well defined, Kreitman et al. [12] recently provided insights into the mechanisms through which $\mathrm{Cu}^{2+}$ interacts with thiols such as $\mathrm{H}_{2} \mathrm{~S}$ in wine-like conditions saturated with oxygen. The manner in which residual copper sulfide (CuS) may affect wine aroma has recently been studied by Clark et al., who firstly showed that once formed, CuS is not easily removed from white wine and that tartaric acid significantly affects CuS precipitation [13]; and secondly, that in both model and finished wines CuS was not measurable as labile copper but that oxidation as well as the loss of volatile thiol compounds through volatilization affects the ratio of labile copper to CuS [14]. These studies demonstrated that when copper and $\mathrm{H}_{2} \mathrm{~S}$ are present in wines, non-labile $\mathrm{CuS}$ will be produced that cannot be removed through filtering and that changes in the wine conditions will affect the ability of copper to remain active/labile to mediate reactions. The ability of copper to mediate $\mathrm{H}_{2} \mathrm{~S}$ formation reactions have been shown in wines where the addition of $\mathrm{Cu}^{2+}$ was associated with significantly increased $\mathrm{H}_{2} \mathrm{~S}$ concentration in wines during bottle aging $[4,10,15]$. Given that a major source of $\mathrm{Cu}^{2+}$ in finished wines is within the control of the winemaker, the timing and amount of $\mathrm{Cu}^{2+}$ can be used to manage $\mathrm{H}_{2} \mathrm{~S}$ formation.

Another important winemaking intervention is the use of sulfur dioxide $\left(\mathrm{SO}_{2}\right)$. The dosage and timing of $\mathrm{SO}_{2}$ addition are similarly key activities under winemaking control and may impact $\mathrm{H}_{2} \mathrm{~S}$ formation. Sulfur dioxide naturally occurs in wines at very low concentrations (10-30 mg/L [16]), however, the main contributor to the final concentration in commercial wines is added $\mathrm{SO}_{2}$ at concentrations in the range of 50-200 mg/L. Sulfur dioxide exists in free and bound forms, with the majority of free $\mathrm{SO}_{2}$ present as bisulfite ions $\left(\mathrm{HSO}_{3}{ }^{-}\right)$at normal wine $\mathrm{pH}$ (all of the different species of sulfur dioxide in equilibrium found in wine, which includes the molecular sulfur dioxide, bisulfite, and sulfite, will be referred to generically as " $\mathrm{SO}_{2}$ " throughout the text). Sulfur dioxide plays a critical role in the prevention of microbial spoilage, and is important as an antioxidant, through reaction with hydrogen peroxide $\left(\mathrm{H}_{2} \mathrm{O}_{2}\right)$ generated from oxygen via a series of redox steps, as well as with quinones to regenerate polyphenols [1,17-20]. It is also known that $\mathrm{SO}_{2}$ influences the loss of thiol compounds post-bottling [21,22]. It has also been proposed that $\mathrm{SO}_{2}$ may act as a source of VSCs. Rankine suggested the reduction of $\mathrm{SO}_{2}$ through the interaction of metal ions such as manganese and zinc with tartaric and malic acids during fermentation [23]. No evidence for the post-bottling formation of $\mathrm{H}_{2} \mathrm{~S}$ via the metal catalyzed reduction of $\mathrm{SO}_{4}{ }^{2-}$ or $\mathrm{SO}_{3}{ }^{2-}$ during low oxygen conditions has yet been shown, even though this pathway has been proposed by Ribéreau-Gayon [24] and Lopes et al. [25]. Another possible pathway through which $\mathrm{SO}_{2}$ can be involved in the modulation of "reductive" VSCs post-bottling is through reactions with wine compounds, such as quinones. Nikolantonaki et al. [26] described the reaction and kinetics between certain o-quinones and nucleophilic thiols and has shown that the addition of $\mathrm{SO}_{2}$ directly influenced the rates and the yields of all of the o-quinone sulfur adducts. Research has demonstrated, using model wine studies, that sulfites, ascorbic acid, and/or GSH can act as sacrificial nucleophiles, suppressing varietal thiol consumption during wine aging [21,22]. 
This competing reaction between $\mathrm{H}_{2} \mathrm{~S}$, methanethiol (MeSH), glutathione, and $\mathrm{SO}_{2}$ has not yet been demonstrated in real wines.

The separate effects that $\mathrm{Cu}^{2+}$ and $\mathrm{SO}_{2}$ additions may have on $\mathrm{H}_{2} \mathrm{~S}$ formation in wines post-bottling have been discussed above, however, $\mathrm{Cu}^{2+}$ and $\mathrm{SO}_{2}$ are usually both present in wine and may have synergistic effects via wine matrix compounds. Given that the final concentrations of $\mathrm{Cu}^{2+}$ and $\mathrm{SO}_{2}$ in finished wines, as well as timing of the addition of $\mathrm{Cu}^{2+}$ and $\mathrm{SO}_{2}$, are under a winemaker's control it is important to understand the synergistic interactions between wine additives such as $\mathrm{Cu}^{2+}$ and $\mathrm{SO}_{2}$ and the effects that these compounds may have on $\mathrm{H}_{2} \mathrm{~S}$ formation. The interactions between $\mathrm{Cu}^{2+}$ and $\mathrm{SO}_{2}$ and its effects on $\mathrm{H}_{2} \mathrm{~S}$ formation have not previously been researched in a structured way in real wines, and this synergistic " $\mathrm{Cu}^{2+}+\mathrm{SO}_{2}$ " interaction may be an additional key contributing factor in the accumulation of $\mathrm{H}_{2} \mathrm{~S}$ post-bottling. The aim of the present study was to investigate the synergistic effects of the combined treatment of $\mathrm{Cu}^{2+}$ and $\mathrm{SO}_{2}$ on $\mathrm{H}_{2} \mathrm{~S}$ formation in a white wine (Verdelho) and a red wine (Shiraz). Some of the factors modulating the formation of $\mathrm{H}_{2} \mathrm{~S}$ via $\mathrm{Cu}^{2+}$ and $\mathrm{SO}_{2}$ interactions during wine storage under low oxygen conditions were also studied.

\section{Results}

\subsection{Dissolved Oxygen}

The dissolved oxygen (DO) was monitored over the course of the experiment using PreSens oxygen sensors applied to representative colorless vials (in triplicate) for a control sample (blank wine) and for each of the treatments $\left(\mathrm{Cu}^{2+}, \mathrm{SO}_{2}\right.$, and " $\mathrm{Cu}^{2+}+\mathrm{SO}_{2}$ ") for the Verdelho $(n=12)$ and for the Shiraz $(n=12)$ wine samples. After two months of storage under low oxygen conditions, both Verdelho and Shiraz samples had consumed all available oxygen and samples can be considered oxygen-free. All samples were stored at room temperature $\left(22^{\circ} \mathrm{C}\right)$ in $19 \mathrm{~L}$ post mix Cornelius kegs (Ambar technology, Alexandria, NSW, Australia). The kegs were flushed with nitrogen gas $\left(\mathrm{N}_{2}(\mathrm{~g})\right.$ ) to $<1 \mathrm{ppb}$ and maintained at a slight positive pressure of $1 \mathrm{psi}_{2(\mathrm{~g})}$ to prevent any oxygen ingress into the keg storage systems, as described by Viviers et al. [10]. As such all wine samples were not exposed to oxygen during storage and only exposed to normal atmospheric oxygen at the point of analysis.

\subsection{Formation of Hydrogen Sulfide in Wine}

\subsubsection{The Effect of $\mathrm{Cu}^{2+}$ on $\mathrm{H}_{2} \mathrm{~S}$ Formation}

Copper treatment did not result in an overall significant effect on $\mathrm{H}_{2} \mathrm{~S}$ formation in the Verdelho samples. Significant increases in $\mathrm{H}_{2} \mathrm{~S}$ concentration were measured after six months of anaerobic storage associated with $\mathrm{Cu}^{2+}$ treatment, however, the overall $\mathrm{Cu}^{2+}$ effect, as measured over the course of the twelve months, was not significant for $\mathrm{H}_{2} \mathrm{~S}$ formation (Figure 1). Hydrogen sulfide is a reactive nucleophile and it has been shown to react readily with quinones in wine-like solutions [21] which may explain the decrease in $\mathrm{H}_{2} \mathrm{~S}$ concentration after the initial increase measured after six months of storage. Only in the Shiraz wine samples did $\mathrm{Cu}^{2+}$ treatment alone result in an overall significant effect on $\mathrm{H}_{2} \mathrm{~S}$ formation. All Shiraz wine samples treated with $\mathrm{Cu}^{2+}$ displayed significant increases in $\mathrm{H}_{2} \mathrm{~S}$ concentration, irrespective of the other additional treatments (Figure 1b, Table 1). Multi-way analysis of variance (ANOVA) confirmed that the increased $\mathrm{H}_{2} \mathrm{~S}$ concentration was significantly correlated with the $\mathrm{Cu}^{2+}$ addition and not associated with interactions between $\mathrm{Cu}^{2+}$ and " $\mathrm{SO}_{2}$ " in the " $\mathrm{Cu}^{2+}+\mathrm{SO}_{2}$ " treatment.

The effect of residual $\mathrm{Cu}^{2+}$ on $\mathrm{H}_{2} \mathrm{~S}$ formation is well established [4,10,27]. All the precursors to $\mathrm{H}_{2} \mathrm{~S}$ have not yet been identified, however, wines with elevated residual $\mathrm{Cu}^{2+}$ concentrations post-bottling risk the formation of $\mathrm{H}_{2} \mathrm{~S}$ during bottle maturation. 

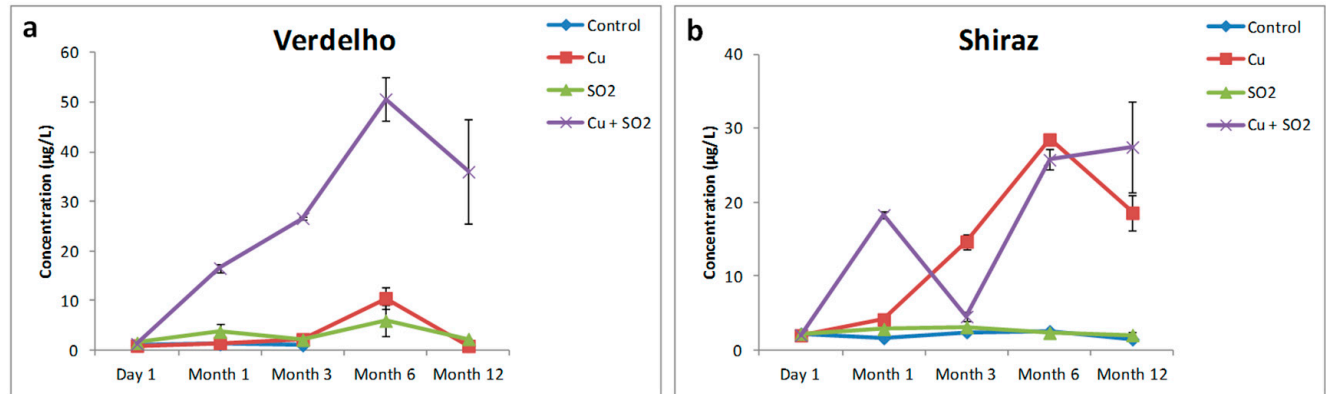

Figure 1. The effects of $\mathrm{Cu}^{2+}, \mathrm{SO}_{2}$, and " $\mathrm{Cu}^{2+}+\mathrm{SO}_{2}$ " on the formation of $\mathrm{H}_{2} \mathrm{~S}$ in (a) Verdelho and (b) Shiraz wine samples that were stored under nitrogen $\left(\mathrm{N}_{2}\right)$ and measured over the course of 12 months.

Table 1. Effects of $\mathrm{Cu}^{2+}, \mathrm{SO}_{2}$, and “ $\mathrm{Cu}^{2+}+\mathrm{SO}_{2}$ " treatments on $\mathrm{H}_{2} \mathrm{~S}$ formation in Verdelho and Shiraz wine samples.

\begin{tabular}{|c|c|c|c|c|c|c|c|c|c|c|c|}
\hline \multicolumn{12}{|c|}{ Verdelho Wine Samples } \\
\hline \multirow{2}{*}{$\mathrm{H}_{2} \mathrm{~S}(\mu \mathrm{g} / \mathrm{L})$} & \multicolumn{2}{|c|}{ DAY 0} & \multicolumn{2}{|c|}{ MONTH 1} & \multicolumn{2}{|c|}{ MONTH 3} & \multicolumn{2}{|c|}{ MONTH 6} & \multicolumn{2}{|c|}{ MONTH 12} & \multirow{2}{*}{$\begin{array}{c}\text { Overall } \\
\text { Significance }\end{array}$} \\
\hline & $\mathrm{AVG}^{1}$ & $\mathrm{SD}^{2}$ & AVG & SD & AVG & SD & AVG & SD & AVG & SD & \\
\hline Control & 1.122 & 0.040 & 1.270 & 0.026 & 1.066 & 0.136 & 2.058 & 0.012 & 0.879 & 0.028 & \\
\hline $\mathrm{Cu}^{2+}$ & 0.981 & 0.062 & 1.523 & 0.062 & 2.276 & 0.428 & 10.53 & 3.776 & 0.923 & 0.395 & ns \\
\hline $\mathrm{SO}_{2}$ & 1.538 & 0.042 & 3.764 & 2.868 & 2.139 & 0.235 & 5.991 & 5.312 & 2.318 & 0.222 & ns \\
\hline $\mathrm{Cu}^{2+}+\mathrm{SO}_{2}$ & 1.338 & 0.137 & 16.59 & 1.527 & 26.64 & 0.683 & 50.62 & 7.685 & 36.01 & 18.09 & $* * * *(+)^{3}$ \\
\hline \multicolumn{12}{|c|}{ Shiraz Wine Samples } \\
\hline \multirow{2}{*}{$\mathrm{H}_{2} \mathrm{~S}(\mu \mathrm{g} / \mathrm{L})$} & \multicolumn{2}{|c|}{ DAY 0} & \multicolumn{2}{|c|}{ MONTH 1} & \multicolumn{2}{|c|}{ MONTH 3} & \multicolumn{2}{|c|}{ MONTH 6} & \multicolumn{2}{|c|}{ MONTH 12} & \multirow{2}{*}{$\begin{array}{c}\text { Overall } \\
\text { Significance }\end{array}$} \\
\hline & AVG & SD & AVG & SD & AVG & SD & AVG & SD & AVG & SD & \\
\hline Control & 2.271 & 0.058 & 1.672 & 0.166 & 2.474 & 0.241 & 2.604 & 0.033 & 1.515 & 0.195 & \\
\hline $\mathrm{Cu}^{2+}$ & 2.063 & 0.066 & 4.202 & 0.354 & 14.71 & 1.701 & 28.50 & 1.048 & 12.41 & 11.00 & $* * * *(+))^{4}$ \\
\hline $\mathrm{SO}_{2}$ & 2.254 & 0.053 & 2.900 & 0.615 & 3.162 & 0.032 & 2.676 & 0.244 & 2.095 & 0.576 & ns \\
\hline $\mathrm{Cu}^{2+}+\mathrm{SO}_{2}$ & 2.096 & 0.101 & 18.31 & 0.886 & 4.594 & 0.977 & 25.77 & 2.364 & 27.49 & 10.75 & $* * * *(+)^{4}$ \\
\hline
\end{tabular}

${ }^{1}$ AVG: Average values for three replicates; ${ }^{2}$ SD: Standard deviation values for three replicates; ${ }^{3} p$-value is the result of significance for the effect, ${ }^{\mu * * * * *}$ indicates $p$-value $\leq 0.001 ;{ }^{4}$ Significant effect associated with " $\mathrm{Cu}^{2+"}$ treatment.

\subsubsection{The Effect of $\mathrm{SO}_{2}$ on $\mathrm{H}_{2} \mathrm{~S}$ Formation}

The treatment of both Verdelho and Shiraz wine samples with $\mathrm{SO}_{2}$ alone had no significant effect on $\mathrm{H}_{2} \mathrm{~S}$ concentration (Figure $1 \mathrm{a}, \mathrm{b}$ ). No increased $\mathrm{H}_{2} \mathrm{~S}$ concentrations were measured by treating Verdelho or Shiraz wines with $\mathrm{SO}_{2}$ alone, suggesting that for the wines investigated in the current study, $\mathrm{SO}_{2}$ is not capable of significantly increasing $\mathrm{H}_{2} \mathrm{~S}$ concentrations when present in wines without $\mathrm{Cu}^{2+}$.

\subsubsection{The Effects of $\mathrm{Cu}^{2+}$ and $\mathrm{SO}_{2}$ Interaction on $\mathrm{H}_{2} \mathrm{~S}$ Formation}

The combined $\mathrm{Cu}^{2+}$ and $\mathrm{SO}_{2}$ treatment in the Verdelho wine samples resulted in significant and large increases in $\mathrm{H}_{2} \mathrm{~S}$ concentrations. For the Verdelho samples more $\mathrm{H}_{2} \mathrm{~S}$ was measured in samples treated with " $\mathrm{Cu}^{2+}+\mathrm{SO}_{2}$ " than by treating samples with $\mathrm{Cu}^{2+}$ alone (Figure 1a). Using multi-way ANOVA it was possible to separate the effects of $\mathrm{Cu}^{2+}$ treatment from the combined $\mathrm{Cu}^{2+}$ and $\mathrm{SO}_{2}$ effects, with the increase in $\mathrm{H}_{2} \mathrm{~S}$ concentration significantly associated with " $\mathrm{Cu}^{2+}+\mathrm{SO}_{2}$ " treatment in the Verdelho samples $(p<0.001$, Table 1$)$. The concentration of $\mathrm{H}_{2} \mathrm{~S}$ produced in Verdelho samples treated with " $\mathrm{Cu}^{2+}+\mathrm{SO}_{2}$ " was $36.01( \pm 18.1) \mu \mathrm{g} / \mathrm{L}$ compared to the $0.879( \pm 0.028) \mu \mathrm{g} / \mathrm{L}$ of $\mathrm{H}_{2} \mathrm{~S}$ measured in the control samples after 12 months of storage under low oxygen conditions, which is a significant increase in $\mathrm{H}_{2} \mathrm{~S}$ concentration.

Significantly increased $\mathrm{H}_{2} \mathrm{~S}$ concentrations were also measured in the Shiraz samples treated with " $\mathrm{Cu}^{2+}+\mathrm{SO}_{2}$ " (Figure 1b). By making use of multi-way ANOVA it was clear that these increases 
were only associated with a significant effect of $\mathrm{Cu}^{2+}(p<0.001$, Table 1$)$ and not associated with the combined $\mathrm{Cu}^{2+}$ and $\mathrm{SO}_{2}$ treatments (Table 1, Figure $1 \mathrm{~b}$ ). If the evolution of $\mathrm{H}_{2} \mathrm{~S}$ in Shiraz samples is considered over the course of the 12 months of storage in a low oxygen environment, the trends of $\mathrm{H}_{2} \mathrm{~S}$ formation for $\mathrm{Cu}^{2+}$ treated samples and samples treated with both $\mathrm{Cu}^{2+}$ and $\mathrm{SO}_{2}$ are remarkably different (Figure 1b). Shiraz samples treated with only $\mathrm{Cu}^{2+}$ displayed a steady increase in $\mathrm{H}_{2} \mathrm{~S}$ concentrations from Month 1 to Month 6, followed by a decrease to Month 12, whereas samples treated with $\mathrm{Cu}^{2+}$ and $\mathrm{SO}_{2}$ displayed an initial increase from Day 0 to Month 1 , followed by a significant decrease in $\mathrm{H}_{2} \mathrm{~S}$ concentrations at Month 3, which was then followed by increased $\mathrm{H}_{2} \mathrm{~S}$ concentrations from Month 6 through to Month 12. The exact mechanism for these different $\mathrm{H}_{2} \mathrm{~S}$ evolution trends are not clear, however, this demonstrates the complex underlying interactions of different wine compounds with one another and how the addition of $\mathrm{SO}_{2}$ to a wine already containing $\mathrm{Cu}^{2+}$ could have significant implications on $\mathrm{H}_{2} \mathrm{~S}$ evolution. Previous studies have also shown the non-linear increase in thiols such as $\mathrm{H}_{2} \mathrm{~S}$ and $\mathrm{MeSH}$ evolution over time [4,5,10], which suggest that compounds such as $\mathrm{H}_{2} \mathrm{~S}$ and MeSH may be dynamically bound and released by other wine compounds after bottling and during storage.

\subsection{Interaction of $\mathrm{Cu}^{2+}$ and $\mathrm{SO}_{2}$ in Model Wine}

\subsubsection{Formation of $\mathrm{H}_{2} \mathrm{~S}$ in Model Wine}

In an effort to identify some of the potential mechanisms involved in modulating the significantly increased $\mathrm{H}_{2} \mathrm{~S}$ concentrations in Verdelho samples treated with " $\mathrm{Cu}^{2+}+\mathrm{SO}_{2}$ ", the experiment was repeated in a model wine containing only water, ethanol $(12 \%)$, and tartaric acid $(10 \mathrm{~g} / \mathrm{L})$. Samples treated with " $\mathrm{Cu}^{2+}+\mathrm{SO}_{2}$ " did not produce similar significant increases in $\mathrm{H}_{2} \mathrm{~S}$ concentrations as was measured in the Verdelho samples treated with " $\mathrm{Cu}^{2+}+\mathrm{SO}_{2}$ " (Figure 2). While there were some changes in $\mathrm{H}_{2} \mathrm{~S}$ concentrations in $\mathrm{SO}_{2}$ treated samples (Figure 2), the increases were small compared to the significantly increased $\mathrm{H}_{2} \mathrm{~S}$ concentrations measured in Verdelho samples treated with " $\mathrm{Cu}^{2+}+\mathrm{SO}_{2}$ " (Figure 1a).

From this experiment, it is clear the increases measured in $\mathrm{H}_{2} \mathrm{~S}$ associated with " $\mathrm{Cu}^{2+}+\mathrm{SO}_{2}$ " treatment require other wine matrix components.

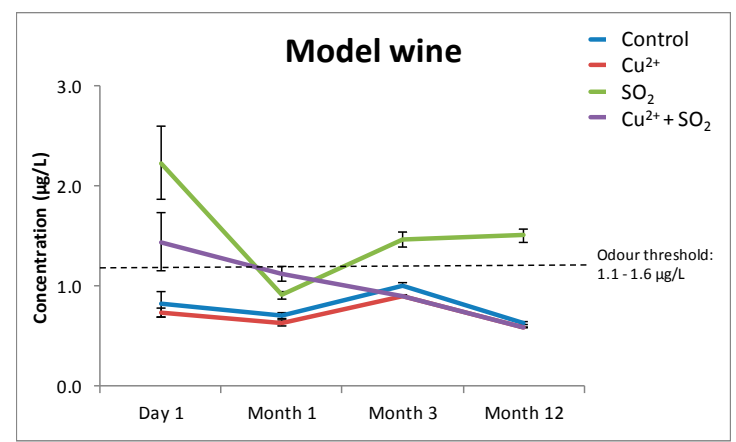

Figure 2. The effects of $\mathrm{Cu}^{2+}, \mathrm{SO}_{2}$, and " $\mathrm{Cu}^{2+}+\mathrm{SO}_{2}$ " on the concentration of $\mathrm{H}_{2} \mathrm{~S}$ in a model wine matrix that did not contain any wine compounds, such as polyphenols or tannins, that could modulate the formation of $\mathrm{H}_{2} \mathrm{~S}$. The odor threshold of $\mathrm{H}_{2} \mathrm{~S}$ (1.1-1.6 $\mu \mathrm{g} / \mathrm{L}$ [28]) is indicated with the dashed line parallel to the $x$-axis. Samples were stored under nitrogen $\left(\mathrm{N}_{2}\right)$ and measured over the course of 12 months.

\subsubsection{Reactions between $\mathrm{H}_{2} \mathrm{~S}$ and $\mathrm{SO}_{2}$ with a Model Wine Compound/Thiol Quenching Compound}

It is known that certain wine matrix compounds, such as quinones, for example, have the ability to readily react with thiols in wine [21] and thus play an important role in modulating the final concentrations of thiols in wines. To investigate the competition reactions between $\mathrm{H}_{2} \mathrm{~S}$ and $\mathrm{SO}_{2}$ with wine matrix compounds capable of reacting with thiols, a model quinone (4-methylbenzoquinone 
(4MBQ)) was synthesized and $\mathrm{H}_{2} \mathrm{~S}$ and $\mathrm{SO}_{2}$ were added to $4 \mathrm{MBQ}$ to produce adducts of $4 \mathrm{MBQ}$ with $\mathrm{H}_{2} \mathrm{~S}$ and $\mathrm{SO}_{2}$. The sulfur containing nucleophiles were first reacted in excess concentration $(4 \mathrm{mM})$ relative to $4 \mathrm{MBQ}(1 \mathrm{mM})$ and the reaction products tentatively identified using high pressure liquid chromatography (HPLC), liquid chromatography-mass spectrometry (LCMS), liquid chromatography-high resolution mass spectrometry (LC-HRMS), and comparison of the mass spectra with published results [21]. All the isomers produced as reaction products from reacting 4MBQ with $\mathrm{H}_{2} \mathrm{~S}$ will from here on be referred to as " $\mathrm{H}_{2} \mathrm{~S}-4 M \mathrm{MC}^{\prime}$ adducts. Similarly, all the isomers produced as reaction products from reacting $4 \mathrm{MBQ}$ with $\mathrm{SO}_{2}$ will from here on be referred to as " $\mathrm{SO}_{2}-4 \mathrm{MC}^{\prime}$. Synthesized $\mathrm{H}_{2} \mathrm{~S}-4 \mathrm{MC}$ and $\mathrm{SO}_{2}-4 \mathrm{MC}$ adducts were used as standards for retention time. The main reaction products are listed in Table 2. The high reactivity of the $\mathrm{SO}_{2}$ and $\mathrm{H}_{2} \mathrm{~S}$ in relation to the $4 \mathrm{MBQ}$ resulted in a high number of isomeric compounds being produced, and for the purpose of this study, only the major isomeric compounds were considered.

Table 2. Mass spectral data and retention times of adducts of 4-methyl benzoquinone with $\mathrm{H}_{2} \mathrm{~S}$ and $\mathrm{SO}_{2}$.

\begin{tabular}{|c|c|c|c|c|c|}
\hline $\begin{array}{c}\mathrm{H}_{2} \mathrm{~S}-4 \mathrm{MC} \text { and } \mathrm{SO}_{2}-4 \mathrm{MC} \\
\text { Adducts }\end{array}$ & $\begin{array}{c}\text { Measured } \\
\text { HRMS }^{2}\end{array}$ & $\begin{array}{l}\text { Predicted } \\
\text { HRMS }^{3}\end{array}$ & $\begin{array}{l}\text { Prediction Accuracy } \\
\text { (err, mDa) }\end{array}$ & $\begin{array}{l}\text { Published } \\
\text { HRMS }^{5}\end{array}$ & $\begin{array}{c}\text { Peak } \\
\text { Ratio }^{6}\end{array}$ \\
\hline \multicolumn{6}{|c|}{$\mathrm{H}_{2} \mathrm{~S}-4 \mathrm{MC}$ adducts: $1 \mathrm{mM} 4 \mathrm{MBQ}+4 \mathrm{mM} \mathrm{H}_{2} \mathrm{~S}$} \\
\hline $4 \mathrm{MC}$ dimer $+\mathrm{SH} ; \mathrm{C}_{14} \mathrm{H}_{13} \mathrm{O}_{4} \mathrm{~S}$ & 277.0543 & 277.054 & -0.3 & 277.0524 & 5 \\
\hline $4 \mathrm{MC}$ dimer $+\mathrm{SH} ; \mathrm{C}_{14} \mathrm{H}_{13} \mathrm{O}_{4} \mathrm{~S}$ & 277.0542 & 277.054 & -0.2 & 277.0524 & 3 \\
\hline $4 \mathrm{MC}$ dimer $+2 \mathrm{SH} ; \mathrm{C}_{14} \mathrm{H}_{13} \mathrm{O}_{4} \mathrm{~S}_{2}$ & 309.0259 & 309.0261 & 0.1 & 309.0240 & 1 \\
\hline \multicolumn{6}{|c|}{$\mathrm{SO}_{2}-4 \mathrm{MC}$ adducts: $1 \mathrm{mM} 4 \mathrm{MBQ}+4 \mathrm{mM} \mathrm{SO}_{2}$} \\
\hline $4 \mathrm{MC}+\mathrm{SO}_{3} ; \mathrm{C}_{7} \mathrm{H}_{7} \mathrm{O}_{5} \mathrm{~S}$ & 203.0024 & 203.0020 & -0.4 & 203.0019 & 2 \\
\hline $4 \mathrm{MC}+\mathrm{SO}_{3} ; \mathrm{C}_{7} \mathrm{H}_{7} \mathrm{O}_{5} \mathrm{~S}$ & 203.0022 & 203.0020 & -0.2 & 203.0019 & 1 \\
\hline $4 \mathrm{MC}$ dimer $+\mathrm{SO}_{3} ; \mathrm{C}_{14} \mathrm{H}_{13} \mathrm{O}_{7} \mathrm{~S}$ & 325.0389 & 325.0387 & -0.1 & $\mathrm{n} / \mathrm{a}$ & 3 \\
\hline $4 \mathrm{MC}$ dimer $+\mathrm{SO}_{3} ; \mathrm{C}_{14} \mathrm{H}_{13} \mathrm{O}_{7} \mathrm{~S}$ & 325.0381 & 325.0387 & 0.7 & $\mathrm{n} / \mathrm{a}$ & 1 \\
\hline \multicolumn{6}{|c|}{$\mathrm{H}_{2} \mathrm{~S}-4 \mathrm{MC}$ and $\mathrm{SO}_{2}-4 \mathrm{MC}$ adducts: $1 \mathrm{mM} \mathrm{4MBQ}+2 \mathrm{mM} \mathrm{H}_{2} \mathrm{~S}+2 \mathrm{mM} \mathrm{SO}_{2}$} \\
\hline $4 \mathrm{MC}$ dimer $+\mathrm{SH} ; \mathrm{C}_{14} \mathrm{H}_{13} \mathrm{O}_{4} \mathrm{~S}$ & 277.0542 & 277.054 & -0.2 & 277.0524 & 4 \\
\hline $4-\mathrm{MC}+\mathrm{SO}_{3} ; \mathrm{C}_{7} \mathrm{H}_{7} \mathrm{O}_{5} \mathrm{~S}$ & 203.0022 & 203.0020 & -0.2 & 203.0019 & 1 \\
\hline $4 \mathrm{MC}$ dimer $+\mathrm{SO}_{3} ; \mathrm{C}_{14} \mathrm{H}_{13} \mathrm{O}_{7} \mathrm{~S}$ & 325.0389 & 325.0387 & -0.1 & $\mathrm{n} / \mathrm{a}$ & 3 \\
\hline $4 \mathrm{MC}$ dimer $+\mathrm{SO}_{3} ; \mathrm{C}_{14} \mathrm{H}_{13} \mathrm{O}_{7} \mathrm{~S}$ & 325.0381 & 325.0387 & 0.7 & $\mathrm{n} / \mathrm{a}$ & 1 \\
\hline \multicolumn{6}{|c|}{$\mathrm{H}_{2} \mathrm{~S}-4 \mathrm{MC}$ and $\mathrm{SO}_{2}-4 \mathrm{MC}$ adducts: wine relevant concentrations } \\
\hline $4 \mathrm{MC}+\mathrm{SO}_{3} ; \mathrm{C}_{7} \mathrm{H}_{7} \mathrm{O}_{5} \mathrm{~S}$ & 203.0022 & 203.0020 & -0.2 & 203.0019 & 1 \\
\hline $4 \mathrm{MC}$ dimer $+\mathrm{SO}_{3} ; \mathrm{C}_{14} \mathrm{H}_{13} \mathrm{O}_{7} \mathrm{~S}$ & 325.0389 & 325.0387 & -0.1 & $\mathrm{n} / \mathrm{a}$ & 5 \\
\hline $4 \mathrm{MC}$ dimer $+\mathrm{SO}_{3} ; \mathrm{C}_{14} \mathrm{H}_{13} \mathrm{O}_{7} \mathrm{~S}$ & 325.0390 & 325.0387 & -0.2 & $\mathrm{n} / \mathrm{a}$ & 1 \\
\hline \multicolumn{6}{|c|}{$\mathrm{H}_{2} \mathrm{~S}-4 \mathrm{MC}$ and $\mathrm{SO}_{2}-4 \mathrm{MC}$ adducts: wine relevant concentrations + metal ions } \\
\hline $4 \mathrm{MC}+\mathrm{SO}_{3} ; \mathrm{C}_{7} \mathrm{H}_{7} \mathrm{O}_{5} \mathrm{~S}$ & 203.0024 & 203.0020 & -0.4 & 203.0019 & 1 \\
\hline $4 \mathrm{MC}$ dimer $+\mathrm{SO}_{3} ; \mathrm{C}_{14} \mathrm{H}_{13} \mathrm{O}_{7} \mathrm{~S}$ & 325.0389 & 325.0387 & -0.1 & $\mathrm{n} / \mathrm{a}$ & 2 \\
\hline $4 \mathrm{MC}$ dimer $+\mathrm{SO}_{3} ; \mathrm{C}_{14} \mathrm{H}_{13} \mathrm{O}_{7} \mathrm{~S}$ & 325.0381 & 325.0387 & 0.7 & $\mathrm{n} / \mathrm{a}$ & 1 \\
\hline $\begin{array}{l}{ }^{1} \text { All } 4 \mathrm{MC} \text {-adducts were tentat } \\
\text { data and by comparison with p } \\
{ }^{4} \text { Accuracy of prediction of mol } \\
\text { molecular formula; }{ }^{5} \text { As publish } \\
\text { product peaks of } 4 \mathrm{MC} \text {-adducts. }\end{array}$ & $\begin{array}{l}\text { identifi } \\
\text { shed resu } \\
\text { y formula } \\
\text { Nikola }\end{array}$ & $\begin{array}{l}\text { ng synthe } \\
\text { ]; }{ }^{2} \text { Meast } \\
\text { r value (m } \\
\text { ki et al. [2 }\end{array}$ & $\begin{array}{l}\text { d adducts for comp } \\
\text { HRMS results; }{ }^{3} \text { Pre } \\
\text { should be }<5 \mathrm{mDa} \text { fo } \\
\text { Peak ratio measured }\end{array}$ & $\begin{array}{l}\text { son of mas } \\
\text { cted molec } \\
\text { ccurate pre } \\
\text { om the mai }\end{array}$ & $\begin{array}{l}\text { pectral } \\
\mathrm{r} \text { mass; } \\
\text { tion of } \\
\text { eaction }\end{array}$ \\
\hline
\end{tabular}

Competition Reactions between $\mathrm{H}_{2} \mathrm{~S}$ and $\mathrm{SO}_{2}$ with a Model Wine Quinone

When 4-methylcatechol (4MC) was oxidized to 4MBQ, the HPLC and LCMS analyses showed only approximately $20 \%$ of the $4 \mathrm{MBQ}$ reacted with the nucleophiles, while the remaining $4 \mathrm{MBQ}$ fraction was converted back to $4 \mathrm{MC}$. This incomplete conversion of $4 \mathrm{MC}$ to $4 \mathrm{MBQ}$ is agreement with previous studies [21]. When $4 \mathrm{MBQ}(1 \mathrm{mM})$ was incubated with $\mathrm{H}_{2} \mathrm{~S}(4 \mathrm{mM})$, three main isomers were formed at a ratio of 5:3:1, and when $4 \mathrm{MBQ}(1 \mathrm{mM})$ was incubated with $\mathrm{SO}_{2}(4 \mathrm{mM})$, four main isomers were formed at a ratio of 2:1:3:1 (Table 2). When 4MBQ (1 mM) was added to model wine containing both sulfur nucleophiles in equimolar concentrations of $2 \mathrm{mM}$ respectively, the same concentration of $\mathrm{H}_{2} \mathrm{~S}-4 \mathrm{MC}$ and $\mathrm{SO}_{2}-4 \mathrm{MC}$ adducts were measured (Figure 3), with a peak ratio of 4:1:3:1 for $\mathrm{H}_{2} \mathrm{~S}-4 \mathrm{MC}$ and the three main $\mathrm{SO}_{2}-4 \mathrm{MC}$ adducts. There were no statistical differences in the total concentrations of 
$\mathrm{H}_{2} \mathrm{~S}-4 \mathrm{MC}$ and $\mathrm{SO}_{2}-4 \mathrm{MC}$ adducts produced $(p=0.193)$. The distribution of the $\mathrm{H}_{2} \mathrm{~S}-4 \mathrm{MC}$ and $\mathrm{SO}_{2}-4 \mathrm{MC}$ adducts remain approximately the same throughout the eight weeks of the experiment (Figure 3).

This experiment demonstrated that when $\mathrm{H}_{2} \mathrm{~S}$ and $\mathrm{SO}_{2}$ are present in equimolar concentrations, both sulfur nucleophiles compete equally for binding to the quinone and a 1:1 ratio of $\mathrm{H}_{2} \mathrm{~S}-4 \mathrm{MC}$ and $\mathrm{SO}_{2}-4 \mathrm{MC}$ adducts are produced.

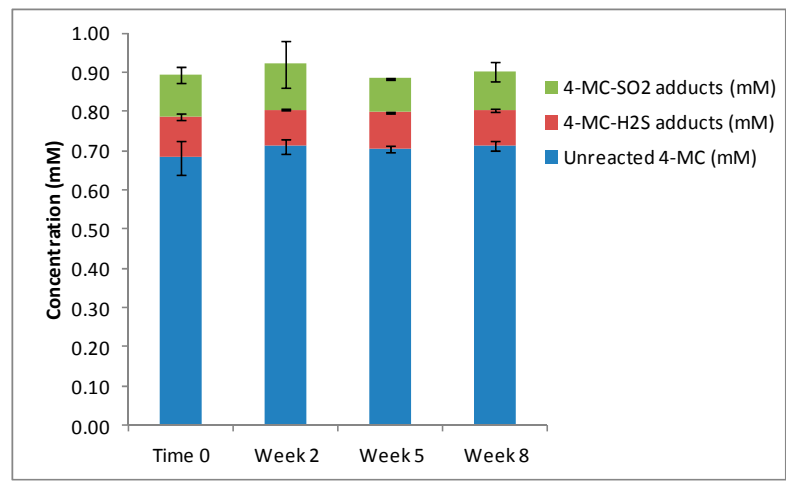

Figure 3. The reaction products measured when $4 \mathrm{MBQ}$ was added to model wine containing equimolar concentrations of $\mathrm{H}_{2} \mathrm{~S}$ and $\mathrm{SO}_{2}$.

Competition Reactions between a Model Wine Quinone with $\mathrm{H}_{2} \mathrm{~S}$ and $\mathrm{SO}_{2}$ at Wine Relevant Concentrations

When $4 \mathrm{MC}$ was oxidized to $4 \mathrm{MBQ}$, and added to model wine containing $\mathrm{H}_{2} \mathrm{~S}$ and $\mathrm{SO}_{2}$ at wine relevant concentrations ( $\left.4 \mathrm{MC}, 0.45 \mathrm{mM} ; \mathrm{H}_{2} \mathrm{~S}, 0.39 \mu \mathrm{M} ; \mathrm{SO}_{2}, 0.23 \mathrm{mM}\right), \mathrm{SO}_{2}$ preferentially reacted with $4 \mathrm{MBQ}$ to form a mixture of $\mathrm{SO}_{2}-4 \mathrm{MC}$ adducts (Figure 4a) even though the spiked $\mathrm{H}_{2} \mathrm{~S}$ was available in the sample to react with $4 \mathrm{MBQ}$ (see $\mathrm{H}_{2} \mathrm{~S}$ concentration data in Figure S1). The peak ratio for the three main $\mathrm{SO}_{2}-4 \mathrm{MC}$ adducts was 1:5:1. Considering that $\mathrm{H}_{2} \mathrm{~S}$ and $\mathrm{SO}_{2}$ have approximately identical first order rate constants when reacting with $4 \mathrm{MBQ}$ [21], it was anticipated that the $\mathrm{SO}_{2}-4 \mathrm{MC}$ adducts would be the main 4-MC adducts produced, but this experiment confirmed that it was indeed the case. This experiment demonstrated that when $\mathrm{H}_{2} \mathrm{~S}$ and $\mathrm{SO}_{2}$ are present in wine relevant concentrations of $0.39 \mu \mathrm{M} \mathrm{H}_{2} \mathrm{~S}$ and $0.23 \mathrm{mM} \mathrm{SO}_{2}$, the $\mathrm{SO}_{2}-4 \mathrm{MC}$ adducts dominate and no $\mathrm{H}_{2} \mathrm{~S}-4 \mathrm{MC}$ adducts can be measured. This suggests that thiol quenching compounds may fully react with sulfur nucleophiles that are present in higher concentrations, such as $\mathrm{SO}_{2}$, and thus allow the accumulation of sulfur nucleophiles present in lower concentrations, such as $\mathrm{H}_{2} \mathrm{~S}$, for example.

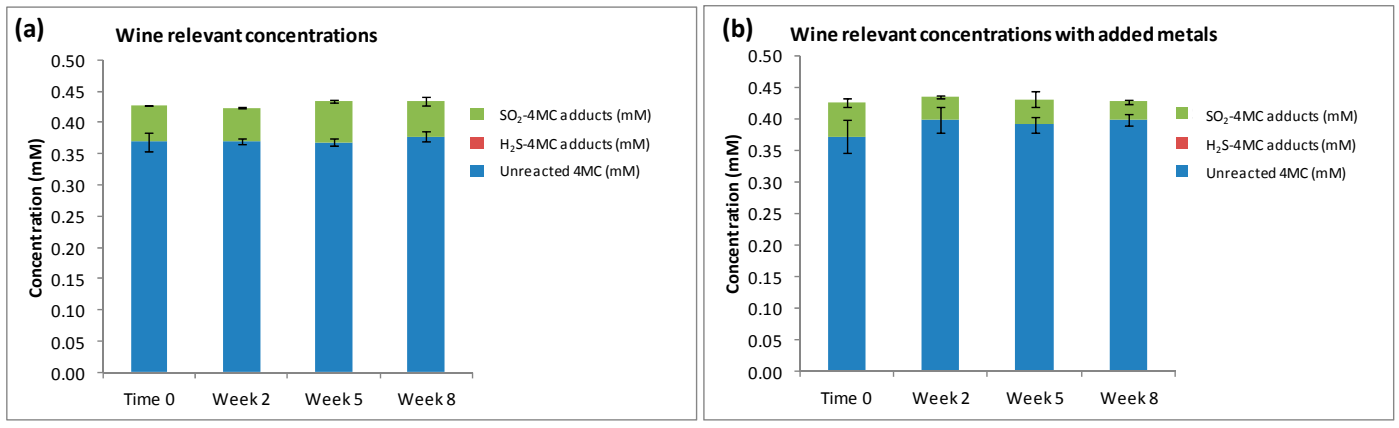

Figure 4. The reaction products measured when $4 \mathrm{MBQ}(0.45 \mathrm{mM})$ was added to model wine containing: (a) wine relevant concentrations of $\mathrm{H}_{2} \mathrm{~S}(0.39 \mu \mathrm{M})$ and $\mathrm{SO}_{2}(0.23 \mathrm{mM})$; and (b) wine relevant concentrations of $\mathrm{H}_{2} \mathrm{~S}(0.39 \mu \mathrm{M}), \mathrm{SO}_{2}(0.23 \mathrm{mM})$, as well as $\mathrm{Cu}^{2+}(0.5 \mathrm{mg} / \mathrm{L})$ and $\mathrm{Fe}^{3+}(4.0 \mathrm{mg} / \mathrm{L})$.

The concentrations of $\mathrm{SO}_{2}-4 \mathrm{MC}$ adducts measured in samples with added $\mathrm{Cu}^{2+}$ and $\mathrm{Fe}^{3+}$ were significantly decreased when compared with the samples without any added metal ions $(p=0.019)$ 
(Figure $4 \mathrm{~b}$ ), and a peak ratio of 1:2:1 was measured for the three main $\mathrm{SO}_{2}-4 \mathrm{MC}$ adducts. This decrease in $\mathrm{SO}_{2}-4 \mathrm{MC}$ adducts may be attributed to the interaction between $\mathrm{SO}_{2}$ and the metal ions when reacting with oxygen as described by Danilewicz [29]. $\mathrm{No}_{2} \mathrm{~S}-4 \mathrm{MC}$ adducts were measured in samples with added metals, even though a small concentration of $\mathrm{H}_{2} \mathrm{~S}$ was measured at Time 0 (Figure $\mathrm{S} 1$ ). $\mathrm{No}_{2} \mathrm{~S}$ was observed in the samples post Time 0 , which may be attributed to the reaction between $\mathrm{Cu}^{2+}$ and $\mathrm{H}_{2} \mathrm{~S}$, a reaction through which $\mathrm{CuS}$ complexes are produced, preventing $\mathrm{H}_{2} \mathrm{~S}$ from reacting with the quinone to produce $\mathrm{H}_{2} \mathrm{~S}-4 \mathrm{MC}$ adducts.

\section{Discussion}

\subsection{Impact of Oxygen on the Formation of $\mathrm{H}_{2} \mathrm{~S}$ from $\mathrm{Cu}^{2+}+\mathrm{SO}_{2}$ Interaction in This Study}

DO was monitored over the course of the experiment using PreSens oxygen sensors applied to representative colorless vials (in triplicate) for a control sample (blank wine) and for each of the treatments $\left(\mathrm{Cu}^{2+}, \mathrm{SO}_{2}\right.$, and " $\mathrm{Cu}^{2+}+\mathrm{SO}_{2}$ ") for the Verdelho $(n=12)$ and for the Shiraz $(n=12)$ wine samples. The rate of oxygen consumption varied between the Verdelho and Shiraz wine samples, with the Shiraz samples consuming the available oxygen faster than the Verdelho samples. The rate of oxygen consumption also varied between the $\mathrm{Cu}^{2+}$ and $\mathrm{SO}_{2}$ treated wine samples (Figure S2). Verdelho samples treated with $\mathrm{SO}_{2}$ displayed the fastest rate of oxygen consumption, and samples treated with $\mathrm{Cu}^{2+}$ also displayed a faster oxygen consumption rate than samples without any added $\mathrm{Cu}^{2+}$ (Figure S2a). The interaction between oxygen and $\mathrm{SO}_{2}$ in wine, the differences in oxygen consumption rates between red and white wine, and the effect of metals on the oxygen consumption rate in wine is in agreement with trends observed by other authors [17,19,24,29]. After two months of storage under low oxygen conditions, both Verdelho and Shiraz samples had consumed all available oxygen and samples can be considered to be effectively oxygen-free (Figure S2a,b).

\subsection{Formation of $\mathrm{H}_{2} \mathrm{~S}$ Associated with $\mathrm{Cu}^{2+}+\mathrm{SO}_{2}$ Treatment}

The role of the interactive effects of residual $\mathrm{Cu}^{2+}$ and free $\mathrm{SO}_{2}$ in the modulation of $\mathrm{H}_{2} \mathrm{~S}$ concentrations in wines post-bottling has not previously been considered. A significant source of $\mathrm{Cu}^{2+}$ in wines is through intentional addition during copper fining remediation treatments, and the dosage and the timing of these $\mathrm{Cu}^{2+}$ additions are determined by the winemaker. Similarly, $\mathrm{SO}_{2}$ can be added pre-fermentation, post-fermentation, during maturation and before bottling. In this study, wines were not previously treated with $\mathrm{Cu}^{2+}$ or $\mathrm{SO}_{2}$. The first additions of $\mathrm{Cu}^{2+}$ and $\mathrm{SO}_{2}$ for the Verdelho and Shiraz wines represented an "at-bottling" treatment for both $\mathrm{Cu}^{2+}$ and $\mathrm{SO}_{2}$. In the Verdelho samples, treatment with " $\mathrm{Cu}^{2+}+\mathrm{SO}_{2}$ " significantly increased $\mathrm{H}_{2} \mathrm{~S}$ concentrations after 12 months of anaerobic storage. Concentrations of up to $36.01( \pm 18.1) \mu \mathrm{g} / \mathrm{L} \mathrm{H}_{2} \mathrm{~S}$ were measured in the " $\mathrm{Cu}^{2+}+\mathrm{SO}_{2}$ " treated Verdelho samples compared to the $0.879( \pm 0.028) \mu \mathrm{g} / \mathrm{L}$ of $\mathrm{H}_{2} \mathrm{~S}$ in the control samples. This study has demonstrated that in wines produced without early $\mathrm{Cu}^{2+}$ and $\mathrm{SO}_{2}$ additions, but treated with these additives before bottling may increase the risk of developing elevated $\mathrm{H}_{2} \mathrm{~S}$ concentrations post-bottling. The high concentration of free $\mathrm{SO}_{2}$ available due to late $\mathrm{SO}_{2}$ treatment just before bottling may explain why the interactive effects of $\mathrm{Cu}^{2+}$ and $\mathrm{SO}_{2}$ were associated with such significant increased $\mathrm{H}_{2} \mathrm{~S}$ concentrations in Verdelho wines.

The exact mechanism for the formation of $\mathrm{H}_{2} \mathrm{~S}$ due to the treatment of Verdelho samples with " $\mathrm{Cu}^{2+}+\mathrm{SO}_{2}$ " is not yet known (Figure 1). It is possible that in the samples spiked with " $\mathrm{Cu}^{2+}$ and $\mathrm{SO}_{2}$ ", $\mathrm{H}_{2} \mathrm{~S}$ is produced through a $\mathrm{Cu}^{2+}$ mediated reaction (Scheme 1, (1)) from unknown precursors naturally present in the wine, either as complexes or in molecular precursor forms. The produced $\mathrm{H}_{2} \mathrm{~S}$ can be quenched through addition to either wine quinones or aldehydes [Scheme 1, (4) and (5)]. However, when a high concentration of free $\mathrm{SO}_{2}$ is available, competing reactions between $\mathrm{SO}_{2}$ and $\mathrm{H}_{2} \mathrm{~S}$ for quinones/aldehydes may occur (Scheme 1, (6), (7), and (8)). It is known that nucleophilic addition reactions compete with the two electron reduction of quinones by $\mathrm{SO}_{2}$ [22]. The first-order rate constants for the addition of $\mathrm{SO}_{2}$ or $\mathrm{H}_{2} \mathrm{~S}$ to quinones are practically identical [21], 
thus the concentration of these nucleophiles determines the preferential addition of $\mathrm{SO}_{2}$ or $\mathrm{H}_{2} \mathrm{~S}$ to quinone molecules. Given that $\mathrm{SO}_{2}$ was added in mM concentrations, whereas $\mathrm{H}_{2} \mathrm{~S}$ was produced in $\mu \mathrm{M}$ concentrations, the addition of $\mathrm{SO}_{2}$ to quinone molecules or the reduction of the quinones via $\mathrm{SO}_{2}$ may be the favored reaction (Scheme 1, (7)). The reaction of bisulfite with wine quinones to produce the sulfonic acid derivative or that reduces the quinone back to its corresponding diphenolic compound [30], may prevent the quenching of thiols and thereby indirectly increase $\mathrm{H}_{2} \mathrm{~S}$ concentrations in the Verdelho samples. Another possible quenching reaction could be through the addition of $\mathrm{H}_{2} \mathrm{~S}$ to wine carbonyl compounds such as acetaldehyde, a compound known to readily react with thiols [31]. The availability of free $\mathrm{SO}_{2}$ and the formation of $\mathrm{H}_{2} \mathrm{~S}$ through $\mathrm{Cu}^{2+}$ mediated reactions would lead to competition reactions between these two sulfur containing molecules for the available carbonyl compound (Scheme 1, (4)), which could result in a higher concentration of $\mathrm{H}_{2} \mathrm{~S}$ in samples treated with $\mathrm{SO}_{2}$ than in treatments without $\mathrm{SO}_{2}$. Another explanation may be the suggested reduction of $\mathrm{SO}_{2}$ by $\mathrm{Cu}^{2+}$ that results in the direct formation of $\mathrm{H}_{2} \mathrm{~S}$ (Scheme 1, (2)), a proposed mechanism for wine post-bottling by Ribéreau-Gayon and Lopes et al. [24,25].

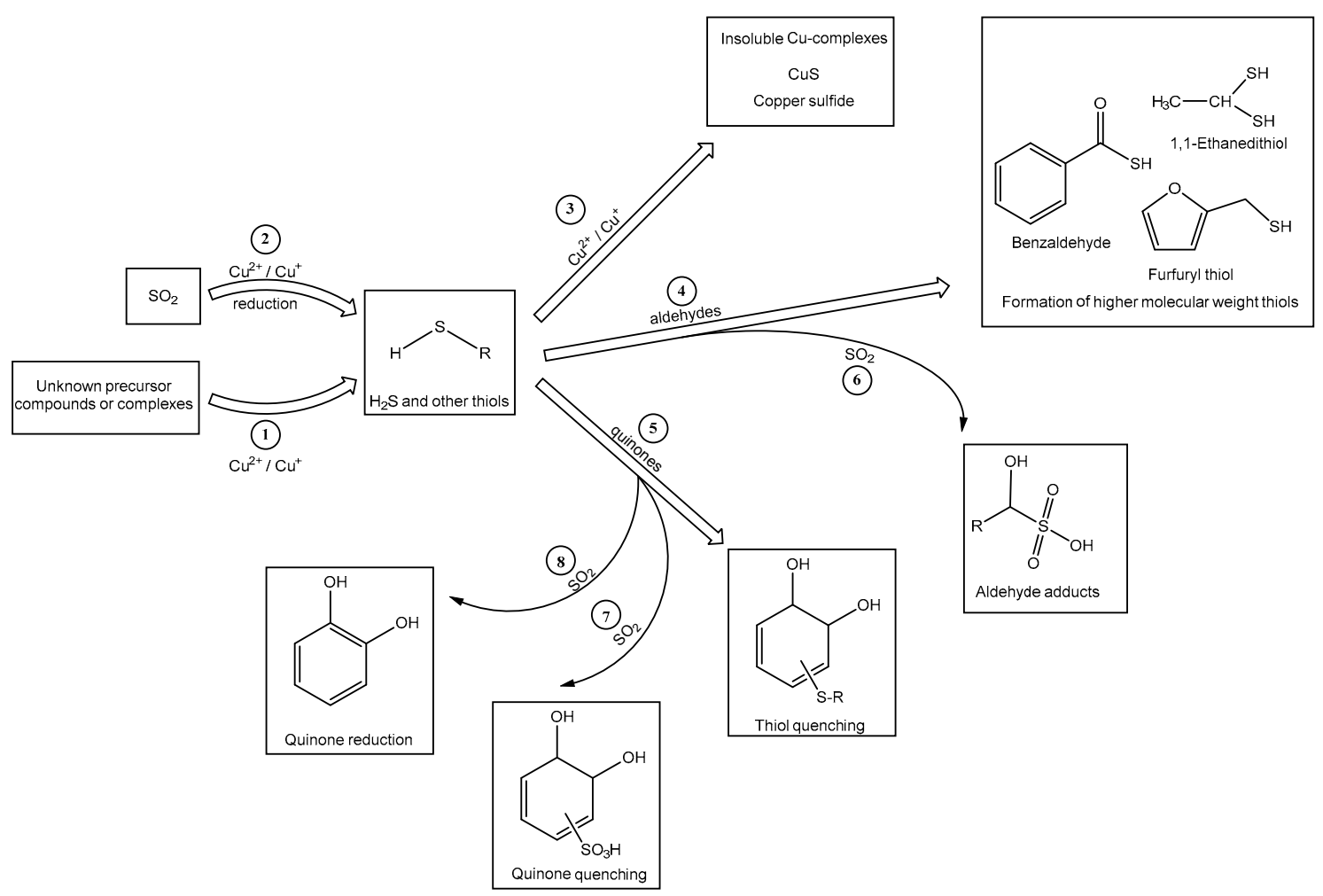

Scheme 1. Possible mechanisms for the formation of $\mathrm{H}_{2} \mathrm{~S}$ and other low molecular weight thiol compounds and the interaction between $\mathrm{Cu}^{2+}, \mathrm{SO}_{2}$, and " $\mathrm{Cu}^{2+}+\mathrm{SO}_{2}$ " with wine compounds such as aldehydes and o-quinones, during $\mathrm{H}_{2} \mathrm{~S}$ formation.

The benefits of treating wine with $\mathrm{SO}_{2}$ offsets the risk of developing "reduced" aromas, and this study demonstrated that even late $\mathrm{SO}_{2}$ additions close to bottling did not pose a risk of increased $\mathrm{H}_{2} \mathrm{~S}$ unless there was a high concentration of residual $\mathrm{Cu}^{2+}$ present in the wines. This study emphasizes the " $\mathrm{Cu}^{2+}+\mathrm{SO}_{2}$ " interaction effect and that increased free $\mathrm{SO}_{2}$ concentrations combined with elevated residual $\mathrm{Cu}^{2+}$ concentrations in wines post-bottling poses a risk of increasing $\mathrm{H}_{2} \mathrm{~S}$ concentrations post-bottling. As such it is important to ensure that residual $\mathrm{Cu}^{2+}$ concentrations, which can be controlled by the winemaker, are kept as low as possible in finished wine.

In the Shiraz samples treated with " $\mathrm{Cu}^{2+}+\mathrm{SO}_{2}$ " the significant increases in $\mathrm{H}_{2} \mathrm{~S}$ concentrations were associated with $\mathrm{Cu}^{2+}$ treatment $(p<0.001$, Table 1$)$ and not associated with the combined $\mathrm{Cu}^{2+}$ and $\mathrm{SO}_{2}$ treatments (Table 1, Figure $1 \mathrm{~b}$ ). It is important to note that the Shiraz wine had approximately 
$50 \%$ less free $\mathrm{SO}_{2}$ than the Verdelho wine, and in red wine a significant proportion of the free $\mathrm{SO}_{2}$ is loosely bound to anthocyanins and other phenolic compounds [17] and as such may not be as available for participation in reactions associated with increased $\mathrm{H}_{2} \mathrm{~S}$ concentrations. In the Verdelho wine samples, a higher concentration of free $\mathrm{SO}_{2}$ was available to be involved in reactions associated with the increase in $\mathrm{H}_{2} \mathrm{~S}$. This difference in free $\mathrm{SO}_{2}$ concentrations may have contributed to the varying effects of $\mathrm{Cu}^{2+}$ and " $\mathrm{Cu}^{2+}+\mathrm{SO}_{2}$ " measured in these two red and white wines. A previous report [10] also showed the varying effect of $\mathrm{Cu}^{2+}$ on $\mathrm{H}_{2} \mathrm{~S}$ formation in Chardonnay relative to Shiraz wines and demonstrated that $\mathrm{H}_{2} \mathrm{~S}$ increased in Shiraz samples spiked with $\mathrm{Cu}^{2+}$ when stored in a low oxygen environment, but not in Chardonnay samples treated in the same way. The opposing $\mathrm{Cu}^{2+}$ effects seen in this study for the Verdelho wine samples relative to Shiraz wine samples again illustrates the complexity of the reactions taking place in wines with different matrices.

\subsection{Mechanisms Modulating $\mathrm{H}_{2} \mathrm{~S}$ Formation}

The experiments described in Section 2.3.1 where the " $\mathrm{Cu}^{2+}+\mathrm{SO}_{2}$ " treatment was applied to model wine demonstrated that no $\mathrm{H}_{2} \mathrm{~S}$ was produced in model wine containing only water, $\mathrm{EtOH}$, tartaric acid, $\mathrm{Cu}^{2+}$, and $\mathrm{SO}_{2}$. This shows that other wine matrix compounds were necessary to produce the significantly increased $\mathrm{H}_{2} \mathrm{~S}$ concentrations measured in the Verdelho samples treated with " $\mathrm{Cu}^{2+}+\mathrm{SO}_{2}$ ". The increased $\mathrm{H}_{2} \mathrm{~S}$ concentration measured in Verdelho samples treated with both " $\mathrm{Cu}^{2+}+\mathrm{SO}_{2}$ " may be the result of the interaction of wine compounds such as wine quinones, aldehydes or any other wine compounds that possess the ability to react with $\mathrm{H}_{2} \mathrm{~S}$.

The quinone (4MBQ) of a representative wine polyphenol (4MC) was added to model wine and the competition reactions between $\mathrm{H}_{2} \mathrm{~S}$ and $\mathrm{SO}_{2}$ were studied at equimolar concentrations as well as at wine relevant concentrations of $\mathrm{H}_{2} \mathrm{~S}$ and $\mathrm{SO}_{2}$. It is known that $\mathrm{H}_{2} \mathrm{~S}$ and $\mathrm{SO}_{2}$ have similar first order rate constants [21] and when $\mathrm{H}_{2} \mathrm{~S}$ and $\mathrm{SO}_{2}$ were added at wine relevant concentrations with $\mathrm{SO}_{2}$ concentrations significantly greater than $\mathrm{H}_{2} \mathrm{~S}$ concentrations, the $\mathrm{SO}_{2}$-quinone adducts were the major reaction product produced. This experiments showed that concentrations in which sulfur nucleophiles are present in wine would determine the major quinone-adduct produced in the case of sulfur nucleophiles with similar first order rate constants. When $\mathrm{H}_{2} \mathrm{~S}$ and $\mathrm{SO}_{2}$ are involved in such competition reactions at wine relevant concentrations, fewer $\mathrm{H}_{2} \mathrm{~S}$ molecules will be quenched through reactions with quinones, leading to an indirect increase in $\mathrm{H}_{2} \mathrm{~S}$ concentrations (Scheme 1 (5) and (7)). These results suggest that the effects of $\mathrm{Cu}^{2+}$ and $\mathrm{SO}_{2}$ may operate independently on separate pathways, but the effects of the additives are cumulative, leading to an increased $\mathrm{H}_{2} \mathrm{~S}$ concentration.

This study has shown that the presence of wine additives, such as $\mathrm{Cu}^{2+}$ and $\mathrm{SO}_{2}$, play a fundamental role in the modulation of $\mathrm{H}_{2} \mathrm{~S}$ profiles in both red and white wine post-bottling. Although the exact reaction pathway for the formation of $\mathrm{H}_{2} \mathrm{~S}$ associated with the combination of $\mathrm{Cu}^{2+}$ and $\mathrm{SO}_{2}$ is not yet known, there are a few possible mechanisms. When a higher ratio of free $\mathrm{SO}_{2}$ to $\mathrm{H}_{2} \mathrm{~S}$ is available, it can form adducts with wine quinones or reduce them back to their corresponding phenols, and in doing so prevent the quenching of the newly formed thiols. Competing reactions between $\mathrm{H}_{2} \mathrm{~S}$ and $\mathrm{SO}_{2}$ could also result in a smaller percentage of $\mathrm{H}_{2} \mathrm{~S}$ lost through, for example, reactions with acetaldehyde. This could indirectly lead to a relative increase in thiol concentration in the treatments with a high concentration of carbonyl compounds. Another explanation may be the suggested reduction of $\mathrm{SO}_{2}$ by $\mathrm{Cu}^{2+}$ that might lead to the formation of $\mathrm{H}_{2} \mathrm{~S}$, as proposed by Ribéreau-Gayon [24] and Lopes et al. [25], although studies in our model wine have not supported this.

Recent work by Franco-Luesma and Ferreira proposed two methods to access $\mathrm{H}_{2} \mathrm{~S}$ production from "loosely bound" vs. "de novo" formation [32]. In this study a method that is comparable with the "total" $\mathrm{H}_{2} \mathrm{~S}$ quantification method was applied that relied on fully releasing all the $\mathrm{H}_{2} \mathrm{~S}$ into the wine headspace through the addition of $2 \mathrm{~g}$ of salt into $10 \mathrm{~mL}$ of wine [28]. As such the $\mathrm{H}_{2} \mathrm{~S}$ loosely bound were fully released, measured and quantified in all samples at the first measurement at Day 0 . The same method was used to analyze the samples over a 12-month period and increased $\mathrm{H}_{2} \mathrm{~S}$ concentrations were statistically significantly associated with the combined " $\mathrm{Cu}^{2+}+\mathrm{SO}_{2}$ " treatment 
and $\mathrm{H}_{2} \mathrm{~S}$ concentration was shown to increase over time in samples, indicating de novo formation of $\mathrm{H}_{2} \mathrm{~S}$ associated with " $\mathrm{Cu}^{2+}+\mathrm{SO}_{2}$ " treatment.

The interactive effects of $\mathrm{Cu}^{2+}$ and $\mathrm{SO}_{2}$ have not previously been explored as a significant factor associated with the accumulation of $\mathrm{H}_{2} \mathrm{~S}$ in wines post-bottling. The majority of commercial wines are treated with $\mathrm{SO}_{2}$ and many contain $\mathrm{Cu}^{2+}$ incorporated through uptake from the soil, pickup during the winemaking process, or by direct addition of $\mathrm{Cu}^{2+}$ through remediation treatments later in production. Fully understanding the timing effects of early and/or late $\mathrm{SO}_{2}$ and $\mathrm{Cu}^{2+}$ additions will help determine whether a wine could be placed at risk of developing elevated $\mathrm{H}_{2} \mathrm{~S}$ concentrations later during storage.

\section{Materials and Methods}

\subsection{Materials}

Amberlyst A26 hydroxide form, ethanol (99.5\%), ethylmethyl sulfide (EMS, 96\%), iron (III) sulfate hydrate (97\%), 4-methylcatechol (4MC, 95\%), periodic acid $(99 \%)$, potassium hydrogen tartrate $(99 \%)$, potassium metabisulfite (PMS, 98\%), and sodium hydrosulfide hydrate $\left(\mathrm{NaSH} \cdot \mathrm{xH}_{2} \mathrm{O}, 71 \%\right)$ were obtained from Sigma-Aldrich (Castle Hill, NSW, Australia). Propyl thioacetate (99.7\%) was obtained from Lancaster Synthesis (Jomar Bioscience, Kensington, SA, Australia). Acetonitrile (ACN, gradient grade for liquid chromatography), methanol (MeOH, $99.8 \%$ by GC), ortho-phosphoric acid ( $85 \%)$, tartaric acid, tetrahydrofuran (THF), and sodium chloride were obtained from Merck (Frenchs Forest, NSW, Australia). Water was obtained from a Milli-Q purification system (Millipore, North Ryde, NSW, Australia). Copper (II) sulfate pentahydrate (99\%) was purchased from Ajax Chemicals (Sydney, NSW, Australia). Formic acid (98\%-100\%) was purchased from Rowe Scientific (Lonsdale, SA, Australia).

\subsection{Wine Samples}

Certified organic Verdelho wine from the 2012 vintage and Shiraz wine from the 2010 vintage, produced in South Eastern Australia, were obtained from a local winery. Neither wine was treated with either $\mathrm{SO}_{2}$ or $\mathrm{Cu}^{2+}$ during winemaking. Analyses of the chemical compositions of the two base wines were conducted by The Australian Wine Research Institute (AWRI) Analytical Service (ISO 17025 Laboratory, Adelaide, Australia) and are as follows: $\mathrm{pH} 3.33,5.8 \mathrm{~g} / \mathrm{L}$ residual sugars, $12.63 \%(v / v)$ alcohol, $0.85 \mathrm{~g} / \mathrm{L}$ volatile acidity (as acetic acid), $6.1 \mathrm{~g} / \mathrm{L}$ titratable acidity (as tartaric acid), $<4 \mathrm{mg} / \mathrm{L}$ free $\mathrm{SO}_{2}$ and $<4 \mathrm{mg} / \mathrm{L}$ total $\mathrm{SO}_{2}$ for the Verdelho wine; and $\mathrm{pH} 3.46,0.7 \mathrm{~g} / \mathrm{L}$ residual sugars, $14.0 \%(v / v)$ alcohol, $0.37 \mathrm{~g} / \mathrm{L}$ volatile acidity (as acetic acid), $6.6 \mathrm{~g} / \mathrm{L}$ titratable acidity (as tartaric acid), $<4 \mathrm{mg} / \mathrm{L}$ free $\mathrm{SO}_{2}$ and $<4 \mathrm{mg} / \mathrm{L}$ total $\mathrm{SO}_{2}$ for the Shiraz wine.

\subsection{Chemical Analyses}

\subsubsection{Oxygen Measurement}

Colorless $20 \mathrm{~mL}$ crimp top vials (Chromacol, Part of Thermo Fisher Scientific Inc., Scoresby, VIC, Australia) were fitted with PreSens Pst6 oxygen sensors (Presens, Regensburg, Germany) and filled with the three treatments $\left(\mathrm{Cu}^{2+}, \mathrm{SO}_{2}\right.$, and " $\mathrm{Cu}^{2+}+\mathrm{SO}_{2}$ ") and control samples (without any treatments) in triplicate for the Verdelho $(n=12)$ and Shiraz wine $(n=12)$ and were used to measure DO during storage of the wines. Samples were stored at $20^{\circ} \mathrm{C}$ under light free conditions and under nitrogen $\left(\mathrm{N}_{2}\right)$ as described by Viviers et al. [10]. Oxygen measurements were carried out using a PreSens Fibox 3 trace v3 oxygen meter, with the limit of detection when using a PtS6 sensor of 1 ppb oxygen. (Presens, Regensburg, Germany).

\subsubsection{Metal Quantifications}

Base wines were analyzed for their metal concentrations by Flinders Analytical, Flinders University (Adelaide, Australia) using an Agilent $7500 \mathrm{cx}$ inductively coupled plasma mass spectrometers (Agilent Technologies, Tokyo, Japan) as described in Thiel et al. [33]. Stock solutions of 
$\mathrm{Cu}^{2+}$ were prepared volumetrically in an anaerobic hood using degassed water (Milli-Q), and then measured for $\mathrm{Cu}^{2+}$ concentrations. The concentrations of total $\mathrm{Cu}^{2+}$ in the base Verdelho and Shiraz wines, as well as the spiked total $\mathrm{Cu}^{2+}$ concentrations in the Verdelho and Shiraz wines are given in Table 3. The stock solution of $\mathrm{Fe}^{3+}$ was prepared as for $\mathrm{Cu}^{2}$.

Table 3. Concentrations of $\mathrm{Cu}^{2+}$ and $\mathrm{SO}_{2}$ in the base wines, spiked samples and average metal and $\mathrm{SO}_{2}$ concentrations for Australian wines.

\begin{tabular}{|c|c|c|c|c|c|c|c|c|c|}
\hline & \multicolumn{2}{|c|}{ Base Concentration } & \multicolumn{3}{|c|}{ Spiked Concentration } & \multirow{2}{*}{ Averages } & \multirow{2}{*}{$\begin{array}{c}\text { Concentration } \\
\text { Range }\end{array}$} & \multicolumn{2}{|c|}{ Legal Limits } \\
\hline & Verdelho & Shiraz & Verdelho & Shiraz & $\begin{array}{l}\text { Model } \\
\text { Wine }\end{array}$ & & & $\begin{array}{l}\text { White } \\
\text { Wine }^{2}\end{array}$ & $\begin{array}{c}\text { Red } \\
\text { Wine }^{2}\end{array}$ \\
\hline $\mathrm{Cu}^{2+}(\mathrm{mg} / \mathrm{L})$ & 0.026 & 0.015 & 1.01 & 0.99 & 1.00 & $0.15^{1}$ & $0.00-1.89^{1}$ & 1 & 1 \\
\hline $\begin{array}{c}\text { Total/free } \\
\mathrm{SO}_{2}(\mathrm{mg} / \mathrm{L})\end{array}$ & $\begin{array}{l}<4.00 / \\
<4.00\end{array}$ & $\begin{array}{l}<4.00 / \\
<4.00\end{array}$ & $\begin{array}{l}98.3 / \\
87.7\end{array}$ & $\begin{array}{c}60.7 / \\
40.8\end{array}$ & $\begin{array}{l}100 / \\
99.67\end{array}$ & $74.0^{3}$ & $10.0>350^{3}$ & 200 & 150 \\
\hline
\end{tabular}

\subsubsection{Determination of $\mathrm{SO}_{2}$}

Base wines and the $\mathrm{SO}_{2}$ stock solution prepared for addition to the samples were analyzed for their free and total $\mathrm{SO}_{2}$ concentrations using the Lachat flow injection analysis (FIA) system by the AWRI Analytical Service (ISO 17025 Laboratory, Adelaide, Australia). Fresh stock solutions of $\mathrm{SO}_{2}$ were prepared volumetrically in an anaerobic hood by dissolving PMS in degassed water (Milli-Q) on the day of the $\mathrm{SO}_{2}$ addition and discarded after use. The concentrations of $\mathrm{SO}_{2}$ in the base Verdelho and Shiraz wines, as well as the spiked $\mathrm{SO}_{2}$ concentrations in the Verdelho, Shiraz, and model wines are given in Table 3.

\subsubsection{Preparation of Reaction Products of $\mathrm{H}_{2} \mathrm{~S}$ and $\mathrm{SO}_{2}$ with 4-Methylbenzoquinone}

The preparation of $4 \mathrm{MBQ}$ by periodate resin was as described by Jongberg et al. [37] and Nikolantonaki et al. [21], with $4 \mathrm{MBQ}$ used immediately after synthesis. The adducts of $\mathrm{SO}_{2}$ and $\mathrm{H}_{2} \mathrm{~S}$, used for retention time reference standards and for the comparison of mass spectral data, were synthesized as follows: $4 \mathrm{MBQ}(1.1 \mathrm{mM})$ was prepared as described by Nikolantonaki et al. [21] and dissolved in cold $\left(4^{\circ} \mathrm{C}\right)$ model wine $(12 \% \mathrm{EtOH}, 10 \mathrm{~g} / \mathrm{L}$ tartaric acid, $\mathrm{pH} 3.4)$ containing $\mathrm{SO}_{2}(4 \mathrm{mM})$ or $\mathrm{H}_{2} \mathrm{~S}(4 \mathrm{mM})$. The reaction mixture was stirred at $20{ }^{\circ} \mathrm{C}$ for $15 \mathrm{~min}$. All reaction products were characterized using LC-HRMS (Table 2), as well as comparing their mass spectra with published spectral data [21].

The competition reaction between $\mathrm{SO}_{2}$ and $\mathrm{H}_{2} \mathrm{~S}$ with $4 \mathrm{MBQ}$ was studied in three separate experiments. First, synthesized $4 \mathrm{MBQ}(1 \mathrm{mM})$ was added to cold $\left(4{ }^{\circ} \mathrm{C}\right)$ model wine $(12 \% \mathrm{EtOH}, 10 \mathrm{~g} / \mathrm{L}$ tartaric acid, $\mathrm{pH} 3.4)$ that already contained $\mathrm{SO}_{2}(2 \mathrm{mM})$ and $\mathrm{H}_{2} \mathrm{~S}(2 \mathrm{mM})$ at equimolar concentrations. The second and third experiments were conducted at wine relevant concentrations, where $4 \mathrm{MBQ}$ $(0.45 \mathrm{mM})[38,39]$ was added to cold $\left(4^{\circ} \mathrm{C}\right)$ model wine $(12 \% \mathrm{EtOH}, 10 \mathrm{~g} / \mathrm{L}$ tartaric acid, $\mathrm{pH} 3.4)$ that already contained either (2) $\mathrm{SO}_{2}(0.23 \mathrm{mM})$ [36] and $\mathrm{H}_{2} \mathrm{~S}(0.39 \mu \mathrm{M})$ [28]; or (3) $\mathrm{SO}_{2}(0.23 \mathrm{mM})$ [36] and $\mathrm{H}_{2} \mathrm{~S}(0.39 \mu \mathrm{M})$ [28] with added $\mathrm{Cu}^{2+}(0.5 \mathrm{mg} / \mathrm{L})$ [34] and $\mathrm{Fe}^{3+}(4.0 \mathrm{mg} / \mathrm{L})$ [34]. In all three experiments, the reaction mixtures were stirred at $20{ }^{\circ} \mathrm{C}$ for $15 \mathrm{~min}$. The reaction between the nucleophiles and $4 \mathrm{MBQ}$ was followed using HPLC. Additionally, residual $\mathrm{H}_{2} \mathrm{~S}$ and $\mathrm{SO}_{2}$ concentrations were measured using GC-SCD and FIA, respectively.

\subsubsection{Analysis of 4-Methylbenzoquinone Adducts Using Liquid Chromatography}

The reaction between $4 \mathrm{MBQ}$ with $\mathrm{SO}_{2}$ and $\mathrm{H}_{2} \mathrm{~S}$ was monitored and the reaction products quantified using the high pressure liquid chromatography (HPLC) as described in Mercurio et al. [40] with slight modification. Briefly, samples were analyzed using an Agilent 1100 LC (Agilent, Mulgrave, 
VIC, Australia) with a Phenomenex Synergi Hydro-RP C18 column (150 mm $\times 2 \mathrm{~mm}, 4 \mu \mathrm{m})$ at $25{ }^{\circ} \mathrm{C}$. Solvent A consisted of $1 \% \mathrm{ACN}$ and $1.5 \%$ phosphoric acid in $\mathrm{H}_{2} \mathrm{O}$, and solvent $\mathrm{B}$ was 80:20 $\mathrm{ACN} /$ Solvent $\mathrm{A}$, for gradient elution at a flow rate of $0.4 \mathrm{~mL} / \mathrm{min}: 0 \mathrm{~min}(0 \%$ solvent $\mathrm{B}), 10 \mathrm{~min}$ (5\% solvent B), $15 \mathrm{~min}(20 \%$ solvent B), $17 \mathrm{~min}(100 \%$ solvent $\mathrm{B})$, and $30 \mathrm{~min}(0 \%$ solvent $\mathrm{B})$.

The reaction products of $4 \mathrm{MBQ}$ with $\mathrm{SO}_{2}$ and $\mathrm{H}_{2} \mathrm{~S}$ were quantified using LCMS as well as LC-HRMS. An Agilent 1200 HPLC system (Forest Hill, Victoria, Australia) equipped with binary pump (1290 model), degasser, autosampler, column oven and diode array detector (DAD) was used. A $5 \mu \mathrm{L}$ aliquot of a sample was injected and separated on a $150 \times 2 \mathrm{~mm}$ i.d., $4 \mu \mathrm{m}, 80 \AA$, Synergi Hydro-RP column connected with a $4 \times 2 \mathrm{~mm}$ i.d. guard column packed with the same material (Phenomenex, Lane Cove, NSW, Australia). The column temperature was maintained at $20^{\circ} \mathrm{C}$ during the HPLC run. A binary gradient with mobile phases consisting of $0.5 \%$ formic acid in water (solvent $\mathrm{A}$ ) and $0.5 \%$ formic acid in acetonitrile (solvent B) was used. The elution conditions were as follows: a flow rate of $400 \mu \mathrm{L} / \mathrm{min}$, a linear gradient of solvent B held at $0 \%$ for $5 \mathrm{~min}$, from 0 to $5 \%$ in $5 \mathrm{~min}$, from $5 \%$ to $20 \%$ in $5 \mathrm{~min}$, from $20 \%$ to $100 \%$ in $2 \mathrm{~min}$ and from $100 \%$ to $0 \%$ for $13 \mathrm{~min}$. A $5 \mathrm{~min}$ re-equilibration time at $0 \%$ of solvent $\mathrm{B}$ was programmed between runs. The effluent from the column was monitored by DAD acquiring absorbance at wavelengths of 254, 280 and $320 \mathrm{~nm}$, followed by introduction to a mass spectrometer through an electrospray (ESI) interface.

For LCMS analysis, a 4000 QTRAP mass spectrometer equipped with a Turbo ion source (Sciex, Mt Waverly, Victoria, Australia) was connected to the outlet of DAD with a PEEK tubing (0.13 mm i.d.). Data acquisition and processing were performed using Analyst software 1.6.2 (Sciex, Mt Waverley, VIC, Australia). ESI negative ion mass spectra were recorded in scan mode ranging from $m / z 50$ to $m / z 1000$ with a scan time of $1 \mathrm{~s}$ and step size of $0.1 \mathrm{Da}$. Nitrogen was used for curtain, nebulizer and heated turbo $\left(500{ }^{\circ} \mathrm{C}\right)$ gases set at $20 \mathrm{psi}, 50 \mathrm{psi}$ and $50 \mathrm{psi}$, respectively. The electrospray and declustering potentials were set at $-4200 \mathrm{~V}$ and $-50 \mathrm{~V}$, respectively.

The LC-HRMS analysis was performed on an Agilent HPLC 1200 coupled to a Bruker microTOF-Q II (Bruker Singapore, The Helios, Singapore). Mass calibration was performed on each file using Bruker Daltonic's DataAnalysis v4.1 "Enhanced Quadratic" calibration method (Bruker Singapore, The Helios, Singapore). All other data analysis including chemical formula predictions was done using Bruker Daltonic's DataAnalysis 4.3. Data were acquired using ESI negative ionisation in scan mode from $m / z$ 50 to 1650 with a scan speed of 2 spectra/s. Nitrogen was used for the nebulizer and dry gas $\left(200{ }^{\circ} \mathrm{C}\right)$ which were set at 2 bar and $7 \mathrm{~L} / \mathrm{min}$, respectively. The capillary voltage was $3500 \mathrm{~V}$ and endplate offset was $-500 \mathrm{~V}$. DAD acquisition range was 200-600 $\mathrm{nm}$.

\subsubsection{Gas Chromatography Coupled to Sulfur Chemiluminescence Detection}

All $\mathrm{H}_{2} \mathrm{~S}$ measurements in the Verdelho and Shiraz base wines, as well as the treated samples, were determined using an Agilent 355 sulfur chemiluminescence detector (SCD) coupled to an Agilent 6890A gas chromatograph (Forest Hill, VIC, Australia). Experimental and analytical parameters, as well as the analysis method were as described by Siebert et al. [28] without modification.

\subsection{Sample Preparation and Analysis}

Preparation of Verdelho, Shiraz, and Model Wine Samples Spiked with $\mathrm{Cu}^{2+}+\mathrm{SO}_{2}$

Wine samples and all stock solutions were prepared in a low oxygen atmosphere by making use of an anaerobic bag (Aldrich ${ }^{\circledR}$ AtmosBag, Sigma-Aldrich, Castle Hill, NSW, Australia) fitted with a PreSens Pst6 oxygen sensor (Presens, Regensburg, Germany). The bag was flushed down to $<1 \mathrm{ppb}$ oxygen with $\mathrm{N}_{2}$ (g) at the start of the sample preparation and a slight positive pressure was maintained to prevent oxygen ingress into the bag during experimental setup. The oxygen concentration in the anaerobic bag was continuously monitored and maintained at $<15 \mathrm{ppb}$. The Verdelho, Shiraz, and model $(12 \% \mathrm{EtOH}, 10 \mathrm{~g} / \mathrm{L}$ tartaric acid, $\mathrm{pH}=3.4)$ base wines were placed inside the anaerobic bag and sub-sampled by placing $10 \mathrm{~mL}$ of wine into a $20 \mathrm{~mL}$ crimp top amber vial (Chromacol, Thermo Fisher 
Scientific Inc., Scoresby, VIC, Australia). The Verdelho and Shiraz wines were each divided into four treatments repeated in triplicate $(n=12):(1) \mathrm{Cu}^{2+}$ treatment $(1 \mathrm{mg} / \mathrm{L}$ for Verdelho, Shiraz and model wines); (2) $\mathrm{SO}_{2}$ treatment (Verdelho: free $87.8 \mathrm{mg} / \mathrm{L}$, total $100.0 \mathrm{mg} / \mathrm{L}$; Shiraz: free $40.8 \mathrm{mg} / \mathrm{L}$, total $60 \mathrm{mg} / \mathrm{L}$; model wine: free $99.67 \mathrm{mg} / \mathrm{L}$, total $100 \mathrm{mg} / \mathrm{L}$ ); (3) " $\mathrm{Cu}^{2+}+\mathrm{SO}_{2}$ " treatment, where the above mentioned levels of $\mathrm{Cu}^{2+}$ and $\mathrm{SO}_{2}$ were combined into one treatment for Verdelho, Shiraz, and model wines; and (4) the control Verdelho, Shiraz, and model wine samples were not treated with either $\mathrm{Cu}^{2+}$ or $\mathrm{SO}_{2}$ (Table 3).

Stock solutions of $\mathrm{Cu}^{2+}$, and $\mathrm{SO}_{2}$ were prepared in such a manner that the high level of each metal was added by spiking $50 \mu \mathrm{L}$ of the appropriate stock solution to the $10 \mathrm{~mL}$ wine sample using a pipette, avoiding significant dilution effects. After the samples were prepared with the four treatments, they were sealed with $20 \mathrm{~mm}$ magnetic crimp caps with $8 \mathrm{~mm}$ center and blue PTFE/silicon septa $(118 \mathrm{~mm})$ (Grace Davison Discovery Sciences, Rowville, VIC, Australia) and stored at room temperature $\left(20^{\circ} \mathrm{C}\right)$ in $19 \mathrm{~L}$ post mix Cornelius kegs (Ambar technology, Alexandria, NSW, Australia). The lid of each keg was fitted with a PreSens Pst6 oxygen sensor (Presens, Regensburg, Germany). The kegs were flushed with $\mathrm{N}_{2}$ (g) until they reached $<1 \mathrm{ppb}$ oxygen and maintained at a slight positive pressure of $1 \mathrm{psi} \mathrm{N}_{2}(\mathrm{~g})$ to prevent any oxygen ingress into the keg storage systems. The kegs were continuously monitored and not allowed to exceed an oxygen measurement of $25 \mathrm{ppb}$, and flushed with $\mathrm{N}_{2}$ (g) to $<1 \mathrm{ppb}$ if increased oxygen concentrations were measured.

Verdelho, Shiraz, and model wine samples were analyzed for their VSC concentrations immediately after spiking with metals (Day 0), and then following 1 month (Month 1), 3 months (Month 3), 6 months (Month 6) and 12 months (Month 12) of storage under low oxygen conditions.

\subsection{Statistical Analyses}

All significance tests (Student's $t$-test, ANOVAs and Tukey analyses) were conducted using GraphPad Prism statistics software (v6.04 GraphPad Software Inc., La Jolla, CA, USA). Multi-way analysis of variance (ANOVA) and Dunnett multiple comparison post-hoc tests were used to determine which treatments were associated with significant effects on the formation of $\mathrm{H}_{2} \mathrm{~S}$ over the course of the 12-month experiment, and statistical significance was assigned if $p<0.05$. All values are represented as mean \pm standard deviation (SD).

Supplementary Materials: The following are available online at http://www.mdpi.com/1420-3049/21/9/1214/s1, Figure S1: Residual $\mathrm{H}_{2} \mathrm{~S}$ concentrations measured in samples that replicated wine-like conditions, with 4MBQ at $0.45 \mathrm{mM}, \mathrm{H}_{2} \mathrm{~S}$ at $0.39 \mu \mathrm{M}$, and $\mathrm{SO}_{2} 0.23 \mathrm{mM}$.; as well as the $4 \mathrm{MBQ}(0.45 \mathrm{mM}), \mathrm{H}_{2} \mathrm{~S}(0.39 \mu \mathrm{M})$, and $\mathrm{SO}_{2}(0.23 \mathrm{mM})$ with added $\mathrm{Cu}^{2+}(0.5 \mathrm{mg} / \mathrm{L})$ and $\mathrm{Fe}^{3+}(4.0 \mathrm{mg} / \mathrm{L})$, Figure S2: Dissolved oxygen consumption measured from Day 0 to Month 12 for: (a) Verdelho samples; and (b) Shiraz samples.

Acknowledgments: The authors would like to thank Cory Black (The Australian Wine Research Institute) for his support and guidance in the synthesis of the SO2-4MC and H2S-4MC adducts, Yoji Hayasaka (The Australian Wine Research Institute) for LCMS analysis, and Natoiya Lloyd of Metabolomics Australia (South Australian Metabolomics Facility, The Australian Wine Research Institute, Adelaide, SA, Australia) for high resolution accurate mass analysis. The authors would also like to thank Geoff Scollary (The University of Melbourne) for critical review of the manuscript. The AWRI is a member of the Wine Innovation Cluster in Adelaide. The work was supported by Australia's grape growers and winemakers through their investment body, the Wine Australia, with matching funds from the Australian Government.

Author Contributions: Mark Smith conceived the idea; Marlize Bekker designed and performed the experiments and analyzed the data; and Eric Wilkes, Paul Smith, and Mark Smith contributed to data interpretation and all authors were involved in the writing of the paper.

Conflicts of Interest: The authors declare no conflict of interest. 


\section{Abbreviations}

The following abbreviations are used in this manuscript:

$\begin{array}{ll}\text { 4MBQ } & \text { 4-methylbenzoquinone } \\ \text { 4MC } & \text { 4-Methylcatechol } \\ \text { ANOVA } & \text { Analysis of variance } \\ \text { AVG } & \text { Average } \\ \text { AWRI } & \text { Australian Wine Research Institute } \\ \text { DO } & \text { Dissolved oxygen } \\ \text { GSH } & \text { Glutathione } \\ \mathrm{H}_{2} \mathrm{O}_{2} & \text { Hydrogen peroxide } \\ \mathrm{H}_{2} \mathrm{~S} & \text { Hydrogen sulfide } \\ \mathrm{HPLC} & \text { High pressure liquid chromatography } \\ \text { LCMS } & \text { Liquid chromatography-mass spectrometry } \\ \text { LC-HRMS } & \text { Liquid chromatography-high resolution mass spectrometry } \\ \mathrm{MeSH} & \text { Methanethiol } \\ \text { MeOH } & \text { Methanol } \\ \mathrm{OT} & \text { Odor threshold } \\ \text { PMS } & \text { Potassium hydrogen tartrate } \\ \text { SO } & \text { Sulfur dioxide } \\ \text { SD } & \text { Standard deviation } \\ \text { THF } & \text { Tetrahydrofuran } \\ \text { VSCs } & \text { Volatile sulfur compounds }\end{array}$

\section{References}

1. Smith, M.E.; Bekker, M.Z.; Smith, P.A.; Wilkes, E.N. Sources of volatile sulfur compounds in wine. Aust. J. Grape Wine Res. 2015, 21, 705-712. [CrossRef]

2. Siebert, T.E.; Bramley, B.; Solomon, M.R. Hydrogen sulfide: Aroma detection threshold study in white and red wine. AWRI Tech. Rev. 2009, 183, 14-16.

3. Villamor, R.R.; Ross, C.F. Wine matrix compounds affect perception of wine aromas. Annu. Rev. Food Sci. Technol. 2013, 4, 1-20. [CrossRef] [PubMed]

4. Ugliano, M.; Kwiatkowski, M.; Vidal, S.; Capone, D.; Siebert, T.; Dieval, J.B.; Aagaard, O.; Waters, E.J. Evolution of 3-mercaptohexanol, hydrogen sulfide, and methyl mercaptan during bottle storage of Sauvignon blanc wines. Effect of glutathione, copper, oxygen exposure, and closure-derived oxygen. J. Agric. Food Chem. 2011, 59, 2564-2572. [CrossRef] [PubMed]

5. Bekker, M.Z.; Day, M.P.; Holt, H.; Wilkes, E.; Smith, P.A. Effect of oxygen exposure during fermentation on volatile sulfur compounds in Shiraz wine and a comparison of strategies for remediation of reductive character. Aust. J. Grape Wine Res. 2016, 22, 24-35. [CrossRef]

6. Day, M.P.; Schmidt, S.A.; Smith, P.A.; Wilkes, E.N. Use and impact of oxygen during winemaking. Aust. J. Grape Wine Res. 2015, 21, 693-704. [CrossRef]

7. Franco-Luesma, E.; Ferreira, V. Reductive off-odors in wines: Formation and release of $\mathrm{H}_{2} \mathrm{~S}$ and methanethiol during the accelerated anoxic storage of wines. Food Chem. 2016, 199, 42-50. [CrossRef] [PubMed]

8. Franco-Luesma, E.; Ferreira, V. Formation and release of $\mathrm{H}_{2} \mathrm{~S}$, methanethiol, and dimethylsulfide during the anoxic storage of wines at room temperature. J. Agric. Food Chem. 2016, 64, 6317-6326. [CrossRef] [PubMed]

9. Nedjma, M.; Hoffmann, N. Hydrogen sulfide reactivity with thiols in the presence of copper(II) in hydroalcoholic solutions cognac brandies: Formation of symmetrical and unsymmetrical dialkyl trisulfides. J. Agric. Food Chem. 1996, 44, 3935-3938. [CrossRef]

10. Viviers, M.Z.; Smith, M.E.; Wilkes, E.; Smith, P. Effects of five metals on the evolution of hydrogen sulfide, methanethiol, and dimethyl sulfide during anaerobic storage of Chardonnay and Shiraz wines. J. Agric. Food Chem. 2013, 61, 12385-12396. [CrossRef] [PubMed]

11. Walker, M.D. The influence of metal-ions on concentrations of flavor-active sulfur-compounds measured in beer using dynamic headspace sampling. J. Sci. Food Agric. 1995, 67, 25-28. [CrossRef]

12. Kreitman, G.Y.; Danilewicz, J.C.; Jeffery, D.W.; Elias, R.J. Reaction mechanisms of metals with hydrogen sulfide and thiols in model wine. Part 1: Copper-catalyzed oxidation. J. Agric. Food Chem. 2016, 64, 4095-4104. [PubMed] 
13. Clark, A.C.; Grant-Preece, P.; Cleghorn, N.; Scollary, G.R. Copper(II) addition to white wines containing hydrogen sulfide: Residual copper concentration and activity. Aust. J. Grape Wine Res. 2015, 21, 30-39. [CrossRef]

14. Clark, A.C.; Kontoudakis, N.; Barril, C.; Schmidtke, L.M.; Scollary, G.R. Measurement of labile copper in wine by medium exchange stripping potentiometry utilising screen printed carbon electrodes. Talanta 2016, 154, 431-437. [CrossRef] [PubMed]

15. Bekker, M.Z.; Mierczynska-Vasilev, A.; Smith, P.A.; Wilkes, E.N. The effects of pH and copper on the formation of volatile sulfur compounds in Chardonnay and Shiraz wines post-bottling. Food Chem. 2016, 207, 148-156. [CrossRef] [PubMed]

16. Jackson, R.S. Wine Science Principles and Applications, 3rd ed.; Elsevier Inc.: San Diego, CA, USA, 2008 ; p. 307.

17. Danilewicz, J.C. Mechanism of autoxidation of polyphenols and participation of sulfite in wine: Key role of iron. Am. J. Enol. Vitic. 2011, 62, 319-328. [CrossRef]

18. Elias, R.J.; Waterhouse, A.L. Controlling the fenton reaction in wine. J. Agric. Food Chem. 2010, 58, $1699-1707$. [CrossRef] [PubMed]

19. Danilewicz, J.C. Reactions involving iron in mediating catechol oxidation in model wine. Am. J. Enol. Vitic. 2013, 64, 316-324. [CrossRef]

20. Waterhouse, A.L.; Laurie, V.F. Oxidation of wine phenolics: A critical evaluation and hypotheses. Am. J. Enol. Vitic. 2006, 53, 306-313.

21. Nikolantonaki, M.; Waterhouse, A.L. A method to quantify quinone reaction rates with wine relevant nucleophiles: A key to the understanding of oxidative loss of varietal thiols. J. Agric. Food Chem. 2012, 60, 8484-8491. [CrossRef] [PubMed]

22. Nikolantonaki, M.; Magiatis, P.; Waterhouse, A.L. Measuring protection of aromatic wine thiols from oxidation by competitive reactions vs wine preservatives with ortho-quinones. Food Chem. 2014, 163, 61-67. [CrossRef] [PubMed]

23. Rankine, B.C. Making Good Wine; Pan Macmillan Australia Pt Limited: Sydney, Australia, 2004; pp. 96-99.

24. Ribereau-Gayon, P.; Glories, Y.; Maujean, A.; Dubourdieu, D. Handbok of Enology: The Chemistry of Wine Stabilization and Treatments, 2nd ed.; John Wiley \& Sons Ltd.: Chichester, UK, 2006; Volume 2, pp. 103, 393. [CrossRef]

25. Lopes, P.; Silva, M.A.; Pons, A.; Tominaga, T.; Lavigne, V.; Saucier, C.; Darriet, P.; Teissedre, P.L.; Dubourdieu, D. Impact of oxygen dissolved at bottling and transmitted through closures on the composition and sensory properties of a sauvignon blanc wine during bottle storage. J. Agric. Food Chem. 2009, 57, 10261-10270. [CrossRef] [PubMed]

26. Nikolantonaki, M.; Jourdes, M.; Shinoda, K.; Teissedre, P.L.; Quideau, S.; Darriet, P. Identification of adducts between an odoriferous volatile thiol and oxidized grape phenolic compounds: Kinetic study of adduct formation under chemical and enzymatic oxidation conditions. J. Agric. Food Chem. 2012, 60, 2647-2656. [CrossRef] [PubMed]

27. Ugliano, M. Oxygen contribution to wine aroma evolution during bottle aging. J. Agric. Food Chem. 2013, 61, 6125-6136. [CrossRef] [PubMed]

28. Siebert, T.E.; Solomon, M.R.; Pollnitz, A.P.; Jeffery, D.W. Selective determination of volatile sulfur compounds in wine by gas chromatography with sulfur chemiluminescence detection. J. Agric. Food Chem. 2010, 58, 9454-9462. [CrossRef] [PubMed]

29. Danilewicz, J.C. Interaction of sulfur dioxide, polyphenols, and oxygen in a wine-model system: Central role of iron and copper. Am. J. Enol. Vitic. 2007, 58, 53-60.

30. Danilewicz, J.C.; Seccombe, J.T.; Whelan, J. Mechanism of interaction of polyphenols, oxygen, and sulfur dioxide in model wine and wine. Am. J. Enol. Vitic. 2008, 59, 128-136.

31. Rauhut, D.; Kurbel, H.; Dittrich, H.H. Sulfur compounds and their influence on wine quality. Wein Wiss. 1993, 48, 214-218.

32. Franco-Luesma, E.; Ferreira, V. Quantitative analysis of free and bonded forms of volatile sulfur compouds in wine. Basic methodologies and evidences showing the existence of reversible cation-complexed forms. J. Chromatogr. A 2014, 1359, 8-15. [CrossRef] [PubMed]

33. Thiel, G.; Geisler, G.; Blechschmidt, I.; Danzer, K. Determination of trace elements in wines and classification according to their provenance. Anal. Bioanal. Chem. 2004, 378, 1630-1636. [CrossRef] [PubMed] 
34. Martin, A.E.; Watling, R.J.; Lee, G.S. The multi-element determination and regional discrimination of Australian wines. Food Chem. 2012, 133, 1081-1089. [CrossRef]

35. Analytical Requirements for the Export of Australian Wine. The Australian Wine Research Institute, 2016. Available online: http://www.awri.com.au/industry_support/regulatory_assistance/export_requirements/ (accessed on 29 June 2016).

36. Peterson, G.F.; Kirrane, M.; Hill, N.; Agapito, A. A comprehensive survey of the total sulfur dioxide concentration of American wines. Am. J. Enol. Vitic. 2000, 51, 189-191.

37. Jongberg, S.; Gislason, N.E.; Lund, M.N.; Skibsted, L.H.; Waterhouse, A.L. Thiol-quinone adduct formation in myofibrillar proteins detected by lc-ms. J. Agric. Food Chem. 2011, 59, 6900-6905. [CrossRef] [PubMed]

38. Fisher, U.; Noble, A.C. The effect of ethanol, catechin concetration, and $\mathrm{pH}$ on sourness and bitterness of wine. Am. J. Enol. Vitic. 1994, 45, 6-10.

39. Komes, D.; Ulrich, D.; Kovacevic, G.; Lovric, T. Study of phenolic and volatile composition of white wine during fermentaion and a short time of storage. Vitis 2007, 46, 77-84.

40. Mercurio, M.D.; Dambergs, R.G.; Herderich, M.J.; Smith, P.A. High throughput analysis of red wine and grape phenolics-adaptation and validation of methyl cellulose precipitable tannin assay and modified Somers color assay to a rapid 96 well plate format. J. Agric. Food Chem. 2007, 55, 4651-4657. [CrossRef] [PubMed]

Sample Availability: Not Available.

(C) 2016 by the authors; licensee MDPI, Basel, Switzerland. This article is an open access article distributed under the terms and conditions of the Creative Commons Attribution (CC-BY) license (http://creativecommons.org/licenses/by/4.0/). 